\title{
Procedural Developments at the International Court of Justice
}

\author{
Fernando Lusa Bordin \\ Sidney Sussex College, University of Cambridge, Cambridge, UK \\ fl29o@cam.ac.uk
}

\begin{abstract}
The present column covers procedural developments at the International Court of Justice for the period 1 February 2019 to 31 March 2021. Those developments comprise jurisdiction ratione materiae under compromissory clauses; procedural preconditions in compromissory clauses; expert opinions; admissibility challenges based on abuse of process and the "clean hands" doctrine; conditions for the indication of provisional measures; and the Court's discretion to give advisory opinions in cases where a request overlaps with a dispute between States.
\end{abstract}

\section{Keywords}

International Court of Justice - compromissory clause - jurisdiction ratione materiae admissibility - abuse of process - "clean hands" doctrine

\section{$1 \quad$ Introduction}

The present column covers procedural developments at the International Court of Justice (ICJ) for the period 1 February 2019 to 31 March 2021. The Court had the occasion to consider several procedural matters in its judgments on preliminary objections in Certain Iranian Assets (Islamic Republic of Iran v. United States of America), Application of the International Convention for the Suppression of the Financing of Terrorism and of the International Convention on the Elimination of All Forms of Racial Discrimination (Ukraine v. Russian Federation), Arbitral Award of 3 October 1899 (Guyana v. Venezuela), 
Alleged Violations of the 1955 Treaty of Amity, Economic Relations, and Consular Rights (Islamic Republic of Iran v. United States of America) and Application of the International Convention on the Elimination of All Forms of Racial Discrimination (Qatarv. United Arab Emirates); its judgment in the Jadhav Case (India v. Pakistan); its advisory opinion on Legal Consequences of the Separation of the Chagos Archipelago from Mauritius in 1965; and the orders it issued in response to requests for provisional measures in Application of the International Convention on the Elimination of All Forms of Racial Discrimination (Qatar v. United Arab Emirates) and Application of the Convention on the Prevention and Punishment of the Crime of Genocide (The Gambia v. Myanmar). ${ }^{1}$ In addition, the Court made some noteworthy changes to its Rules and Practice Directions.

In the following pages, the main procedural developments arising from those decisions are described and discussed. Those developments comprise jurisdiction ratione materiae under compromissory clauses; procedural preconditions in compromissory clauses; the procurement of expert opinions; admissibility challenges based on abuse of process and the "clean hands" doctrine; conditions for the indication of provisional measures; and the Court's discretion to give advisory opinions in cases where a request overlaps with a dispute between States.

Pursuant to Article 13(1) of the ICJ Statute, five out of the fifteen judges composing the Court's permanent bench are elected (or re-elected) every three years. ${ }^{2}$ Judges are elected by an absolute majority of votes in the General Assembly and Security Council of the United Nations, which hold concurrent but separate ballots. ${ }^{3}$ The most recent triennial elections took place at the UN Headquarters in New York City in November 2020. Judges Xue (China), Tomka (Slovakia), Sebutinde (Uganda) and Iwasawa (Japan) were re-elected to serve

1 The Court has also rendered judgments in Appeal Relating to the Jurisdiction of the ICAO Council under Article 84 of the Convention on International Civil Aviation (Bahrain, Egypt, Saudi Arabia and United Arab Emirates v. Qatar), Judgment of 14 July 2020, and Immunities and Criminal Proceedings (Equatorial Guinea v. France), Judgment of 11 December 2020.

2 Art. 13(1) ICJ Statute: "The members of the Court shall be elected for nine years and may be re-elected; provided, however, that of the judges elected at the first election, the terms of five judges shall expire at the end of three years and the terms of five more judges shall expire at the end of six years."

3 Arts. 4 and 10 of the ICJ Statute. 
for another nine-year term, and Professor Georg Nolte (Germany) was elected as a new Member of the Court, taking Judge Gaja's place on the bench. ${ }^{4}$

The Court also appointed a new Registrar, Mr. Philippe Gautier, following Mr. Philippe Couvreur's retirement from the office on 30 June 2019. ${ }^{5} \mathrm{Mr}$. Gautier, a Belgian national and former Registrar of the International Tribunal for the Law of the Sea, started his seven-year term on 1 August 2019. ${ }^{6}$

On 8 February 2021, the Court held elections for the offices of President and Vice-President. Judge Joan Donoghue (United States of America) was elected President of the Court, and Judge Kirill Gevorgian (Russian Federation) was elected Vice-President. ${ }^{7}$ On the same date, elections were held for the Chamber of Summary Procedure established under Article 29 of the ICJ Statute, ${ }^{8}$ and for three Committees: the Budgetary and Administrative Committee, the Rules Committee and the Library Committee.

In the period covered, the ICJ amended Articles 22, 23, 29, 59, 76, 79 and 94 of the Rules of Court. ${ }^{9}$

Articles 22, 23 and 29 concern the election and removal of the Registrar and Deputy-Registrar. Following its amendment, Article 22 no longer requires that a candidate for the post of Registrar be proposed by a Judge. It rather envisages a selection process, to be normally commenced six months prior to the end of the term of an incumbent Registrar, where a vacancy announcement is published to invite applications for the post. Article 29 has been amended to clarify that a decision to remove a Registrar or Deputy-Registrar from office requires a two-thirds majority of "the Members of the Court composing it at the time of the decision to be taken". Such a decision is to "be taken by secret ballot".

4 See I.C.J. Press Release 2020/33, 13 November 2020.

5 I.C.J. Press Release 2019/4, 15 February 2019.

6 I.C.J. Press Release 2019/32, 1 August 2019.

7 I.C.J. Press Release 2021/7, 8 February 2021.

8 Art. 29 ICJ Statute: "With a view to the speedy dispatch of business, the Court shall form annually a chamber composed of five judges which, at the request of the parties, may hear and determine cases by summary procedure. In addition, two judges shall be selected for the purpose of replacing judges who find it impossible to sit".

9 See I.C.J. Press Release 2019/42, 21 October 2019 (explaining and describing the amendments to Articles 22, 23, 29, 76 and 79 of the Rules of Court) and I.C.J. Press Release 2020/16, 25 June 2020 (explaining and describing the amendments to Articles 59 and 94 of the Rules of Court). 
Article 76 concerns modifications or revocations of the Court's decisions to indicate provisional measures. It has been amended to make it clear that the Court has the power to modify or revoke provisional measures propio motu.

Article 79 regulates the submission of preliminary objections to the Court's jurisdiction and concerning the admissibility of claims. The Court has reorganised the provisions found in Article 79 into three separate articles, adding thus an Article 79bis and an Article 79ter to the Rules of Court. In this new configuration, Article 79 deals with preliminary questions of jurisdiction and admissibility that the Court itself identifies; Article 79bis covers preliminary objections filed by the parties; and Article 79ter comprises procedural rules that are common to both of those scenarios.

Finally, Articles 59 and 94, concerning the conduct of hearings and the reading of judgments, have been amended in response to the challenges that the COVID-19 pandemic has posed to the functioning of the Court. The amended provisions make it possible for the Court to hold hearings and read judgments by video link whenever "health, security or other compelling reasons" are present.

Two further changes to the Court's procedure must be noted. First, a new Article 11 has been added to the Resolution concerning the Internal Judicial Practice of the Court, establishing a procedure for monitoring the implementation of provisional measures..$^{10}$ Article 11 comprises the following three paragraphs:

(i) Where the Court indicates provisional measures, it shall elect three judges to form an ad hoc committee which will assist the Court in monitoring the implementation of provisional measures. This committee shall include neither a Member of the Court of the nationality of one of the parties nor any judges ad hoc.

(ii) The ad hoc committee shall examine the information supplied by the parties in relation to the implementation of provisional measures. It shall report periodically to the Court, recommending potential options for the Court.

(iii) Any decision in this respect shall be taken by the Court.

Second, Practice Direction III has been amended so that it now imposes a page limit for the annexes to written pleadings submitted by the parties. ${ }^{11}$ Under

10 I.C.J. Press Release 202O/38, 21 December 2020.

11 I.C.J. Press Release 2O21/2, 20 January 2021. 
Practice Direction III, the parties are urged to "keep the written pleadings as concise as possible" and to append to those pleadings "only strictly selected documents". Following the amendment, those selected documents are now subject to a limit of $75^{\circ}$ pages unless the Court decides otherwise on the request of the parties.

\section{$4 \quad$ Jurisdiction in Contentious Proceedings}

\subsection{Jurisdiction ratione materiae under Compromissory Clauses}

In the period reported, the Court had the occasion to interpret the compromissory clauses of three treaties with a view to determining whether it had jurisdiction ratione materiae to decide on the merits of four different cases. While the structure of the Court's reasoning in the judgments varies in accordance with the issues raised by the parties, a blueprint for the analysis of jurisdiction ratione materiae seems to have consolidated in the Court's jurisprudence. First, the Court identifies the subject-matter of the dispute "on an objective basis ... by isolating the real issue in the case and identifying the object of the claim", while "giving particular attention to the formulation of the dispute chosen by the applicant" and taking into account "the facts that the applicant presents as the basis for its claim.". ${ }^{2}$ Second, the Court assesses whether the "acts of which the applicant complains fall within the provisions of the treaty containing the compromissory clause"13 or, more broadly stated, "within the scope" of that treaty. ${ }^{14}$ Third, in order to carry out that assessment, the Court interprets the treaty containing the compromissory clause in the light of the customary tenets of treaty interpretation articulated in Articles $3^{1}$ and 32 of the 1969 Vienna Convention on the Law of Treaties. ${ }^{15}$ It sometimes

12 See Application of the International Convention for the Suppression of the Financing of Terrorism and of the International Convention on the Elimination of All Forms of Racial Discrimination (Ukraine v. Russian Federation), Preliminary Objections, Judgment, I.C.J. Reports 2019, para. 24; Application of the International Convention on the Elimination of All Forms of Racial Discrimination (Qatar v. United Arab Emirates), Judgment of 4 December 2020, para. 42; Alleged Violations of the 1955 Treaty of Amity, Economic Relations, and Consular Rights (Islamic Republic of Iran v. United States of America), Judgment of 3 February 2021, para. 52 .

13 Alleged Violations of the 1955 Treaty of Amity, para. 75. Essentially identical language is used in Application of ICSFT and CERD, para. 57.

14 Certain Iranian Assets (Islamic Republic of Iran v. United States of America), Preliminary Objections, Judgment, I.C.J. Reports 2019, para. 52; Application of CERD (Qatar V. UAE), para. 72 .

15 Application of ICSFT and CERD, paras. 59-63; Application of CERD (QAatar v. UAE), paras. $75^{-76 .}$ 
does that rather methodically, considering the ordinary meaning of relevant provisions; the context in which those provisions are inserted; the object and purpose of the treaty; the subsequent practice of the parties; the travaux préparatoires as necessary for confirming the meaning of the text or avoiding ambiguous or absurd readings; and, whenever available, decisions by other courts, tribunals or entities tasked with interpreting the treaty. ${ }^{16}$

\subsubsection{Certain Iranian Assets}

Iran has two pending cases against the United States, both brought under the Treaty of Amity, Economic Relations, and Consular Rights that the two States concluded in 1955. Pursuant to Article XXI of the Treaty of Amity:

Any dispute between the High Contracting Parties as to the interpretation or application of the present Treaty, not satisfactorily adjusted by diplomacy, shall be submitted to the International Court of Justice, unless the High Contracting Parties agree to settlement by some other pacific means.

The first case is Certain Iranian Assets, where Iran complains about a number of measures taken by the United States against Iranian companies, including against Bank Markazi (Iran's Central Bank). Iran alleges that those measures breach the Treaty of Amity insofar as they, among other things, treat Iranian entities in an unfair and discriminatory manner, fail to accord to them constant protection and security, and have the effect of expropriating the assets of those entities. A central claim that Iran makes in this connection is that the United States breached the Treaty of Amity by disregarding the immunity enjoyed by Iran and Iranian State-owned entities.

Reacting to Iran's Application, the United States made three objections relating to the Court's jurisdiction ratione materiae: (i) that the Court's jurisdiction is excluded by Article Xx of the Treaty of Amity; (ii) that Iran's claim relating to State immunity falls outside the scope of the Treaty of Amity; and (iii) that the treatment of Bank Markazi, as a sovereign entity, does not trigger the application of the Treaty of Amity, which only concerns private companies. The Court unanimously rejected the first objection, and, by a majority of eleven to four, upheld the second and decided that the third does not possess an exclusively preliminary character. ${ }^{17}$

Article Xx is a provision in the Treaty of Amity which prescribes that certain measures adopted by the parties are not precluded by the Treaty. That

16 Notably in Application of CERD (Qatar V. UAE), para. 77.

17 Certain Iranian Assets, para. 126. 
provision had been construed by the Court in the Oil Platforms case in 1996..$^{18}$ Restating the view it took then, the Court rules that the Treaty of Amity "contains no provision expressly excluding certain matters from its jurisdiction", and that Article $\operatorname{xx}(1)(d)$ (referring to international peace and security and the parties' security interests) is "confined to affording the Parties a possible defence on the merits to be used should the occasion arise".19 The Court observes that the same is true of $\operatorname{Article} \mathrm{xx}(1)(\mathrm{c})$, which concerns "the production of or traffic in arms". ${ }^{20}$ As a result, the first objection made by the United States is rejected.

The United States based its second objection on the fact that the Treaty of Amity does not expressly require the parties to accord State immunity to one another. On its part, Iran sought to rely on a number of provisions that it claimed should be construed as implying a treaty obligation to respect immunity, namely: Article IV(2), committing the United States to offer "most constant protection and security ... in no case less than that required by international law"; Article XI(4), prescribing that publicly owned or controlled entities shall not enjoy immunity if they engage in "commercial, industrial, shipping or other business activities"; Article III(2), ensuring "freedom of access to the courts of justice and administrative agencies" to "nationals and companies" from each of the parties; Article IV(1), creating an obligation to accord fair and equitable treatment to, and to refrain from "unreasonable or discriminatory measures" against, nationals and companies from the other party; and Article $\mathrm{x}(1)$, providing for "freedom of commerce and navigation" between the parties.

The Court disagrees that those provisions would have the effect of bringing breaches of State immunity within the purview of the Treaty of Amity. It finds that, given the object and purpose of the treaty, the reference to international law in Article IV(2) concerns the "minimum standard of treatment of protection for property" under international law, not the rules of State immunity. ${ }^{21}$ The arguments based on Article III(2) and Article x(1) likewise failed, the former because the Court did not think that Article III (2) conferred specific "substantive or even the procedural rights" on companies or nationals of the parties (such as the right to assert immunity), ${ }^{22}$ the latter because the

18 Oil Platforms (Islamic Republic of Iran v. United States of America), Preliminary Objection, Judgment, I.C.J. Reports 1996.

19 Certain Iranian Assets, para. 45.

$20 \quad$ Ibid., para. 46.

21 Ibid., para. 57. A similar line of reasoning is employed in the Court's interpretation of Art. IV(1) of the Treaty of Amity (para. 74). For criticism of this position, see Certain Iranian Assets, Separate Opinion of Judge ad hoc Momtaz, paras. 11-12 and 21.

22 Certain Iranian Assets, para. 7o. For criticism of this position, see the Separate Opinion of Judge Gevorgian, para. 9 . 
Court did not think that freedom of commerce could "cover matters that have no connection, or too tenuous a connection, with the commercial relations between the States Parties to the Treaty" (as is the case with State immunity). ${ }^{23}$

Most interesting was the Court's discussion of $\operatorname{Article~XI(4),~a~provision~that,~}$ unlike the others, expressly refers to immunity. Iran had sought to rely on an a contrario interpretation of that provision, suggesting that the express reference to the unavailability of immunity for commercial transactions performed by publicly owned enterprises was an indication that the Treaty of Amity had sought to regulate issues of State immunity. But the Court finds that neither the text nor the context of Article XI(4) supports the inference that the provision has the effect of "transforming compliance with such immunities into a treaty obligation". ${ }^{24}$ It construes the reference to the unavailability of immunity for commercial transactions narrowly in the light of the Treaty of Amity's object and purpose, namely to "preserve fair competition among economic actors operating in the same market", to which it believes the "questions of activities jure imperii are simply not germane". 25

The Court's reasoning was criticised by three judges, who took a different view as to the Treaty of Amity's object and purpose. Judge Robinson wrote an eloquent Separate Opinion where he argues that Article XI(4) "requires recourse to customary international law to ascertain whether such acts are entitled to immunity" because "the enjoyment of immunity by a State entity for sovereign, governmental acts is vital to the achievement of [the Treaty of Amity's] object and purpose", namely "to maximize trade, investment and economic relations between the two countries". ${ }^{26} \mathrm{He}$ adds that measures stripping Bank Markazi of immunity had "an adverse effect on the discharge by the Bank of its functions and are precisely the kind of measures that the Treaty was intended to prevent and regulate". ${ }^{27}$ Likewise, Judge Gevorgian and Judge ad hoc Momtaz emphasise the link between the unimpeded functioning of Bank Markazi and the implementation of the treaty. Judge Gevorgian notes that "Bank Markazi plays a crucial role in the conclusion of commercial transactions by Iranian companies in the US, to the point that the attachment of its assets may have rendered such transactions impossible", thus frustrating the Treaty of Amity. ${ }^{28}$ Judge ad hoc Momtaz describes "the Parties' compliance

\footnotetext{
23 Ibid., para. 79.

24 Ibid., para. 64.

25 Ibid.

26 Certain Iranian Assets, Separate Opinion of Judge Robinson, para. 7.

27 Ibid., para. 12. Judge Robinson also explores the connection between Art. XI(4) and Art. VII of the Treaty of Amity.

28 Certain Iranian Assets, Separate Opinion of Judge Gevorgian, para. 5 .
} 
with their international obligations concerning the activities and assets of a central bank (jure imperii), as well as the immunities associated therewith" as a "a precondition for upholding the specific rights and obligations provided for in the Treaty".29 In contrast, Judge ad hoc Brower wrote in support of the majority's approach, noting that the "express grants of immunities for the purposes of consular and diplomatic relations" in the Treaty of Amity "stand in stark contrast to the total absence of any express grant of immunity for any other purpose, including in respect of economic relations". ${ }^{30}$ That, for him, suggests that the Treaty of Amity should not be construed as granting immunity to State entities.

The Court's decision to uphold the second preliminary objection made by the United States is in keeping with its recent judgment on preliminary objections in the Immunities and Criminal Proceedings (Equatorial Guinea $v$. France) case. In that judgment, the Court rejected the argument that a provision in the UN Convention against Transnational Organized Crime requiring the parties to apply the Convention "in a manner consistent with the principles of sovereign equality and territorial integrity of States and that of non-intervention in the domestic affairs of other States" meant that respect for State immunity and the immunity of State officials was an obligation imposed by the Convention itself. ${ }^{31}$ It appears, therefore, that the Court has been taking a circumspect approach when faced with arguments that the application of rules of customary international law fall within the scope of specific treaties with which those rules have a tenuous connection.

The third preliminary objection that the United States made was that Iran's claims regarding the treatment of Bank Markazi fell outside the scope of the Treaty of Amity because Bank Markazi was not a "company" in the sense in which the term is employed in the treaty. The point of contention between the parties was whether the nature of the activities of Bank Markazi, as the Central Bank of Iran, should have a bearing on its characterisation as a "company". The Court agrees with the United States that, in the light of the object and purpose of the Treaty of Amity, "an entity carrying out exclusively sovereign activities, linked to the sovereign functions of the State, cannot be characterized

\footnotetext{
29 Certain Iranian Assets, Separate Opinion of Judge ad hoc Momtaz, para. 12.

30 Certain Iranian Assets, Separate Opinion of Judge ad hoc Brower, para. 15.

31 Immunities and Criminal Proceedings (Equatorial Guineav. France), Preliminary Objections, I.C.J. Reports 2018, paras. 91-102 (discussed in Bordin, "Procedural Developments at the International Court of Justice", 18 The Law and Practice of International Courts and Tribunals (2019), 101, 103-109). For an attempt to distinguish between the two cases, see Certain Iranian Assets, Separate Opinion of Judge Gevorgian, para. 4.
} 
as a 'company' within the meaning of the Treaty". ${ }^{32}$ The Court accepts, however, that "there is nothing to preclude, a priori, a single entity", such as Bank Markazi, "from engaging both in activities of a commercial nature ... and in sovereign activities". It follows that any measures targeting Bank Markazi while the Bank was involved in business activities could fall within the scope of the Treaty of Amity. But the Court concludes that this is not a question possessing an exclusively preliminary character in the sense of Article 79(9) of the Rules of Court. ${ }^{33}$ That was because the Court did not have "before it all the facts necessary to determine whether Bank Markazi was carrying out, at the relevant time, activities of the nature of those which permit characterization as a 'company' within the meaning of the Treaty of Amity". ${ }^{34}$

This decision attracted the dissent of four judges. In a joint Separate Opinion, Judges Tomka and Crawford contend that the Court had all the required information about Bank Markazi and should accordingly have made a definitive finding as to whether the Bank qualified as a "company" under the Treaty of Amity. ${ }^{35}$ They go through the history of the provision now found in Article 79ter(4) of the Rules of Court, with a view to showing that it creates a "presumption in favour of a decision at the preliminary stage, rather than joinder to the merits" - a presumption from which, they believe, the Court departed. ${ }^{36}$ Judge Gaja and Judge ad hoc Brower also share the view that the Court should have dealt with the US objection as a preliminary matter, though they take opposite positions as to what the Court's conclusion on jurisdiction should have been. Judge Gaja says that the US objection ought to have been rejected because "[w] hat is required is for the Court to ascertain that a reasonable case has been made that Bank Markazi enjoys rights under Articles III, IV or V of the Treaty and that these rights may have been violated", a threshold that, he thinks, had been met. ${ }^{37}$ Judge ad hoc Brower, in contrast, would have wished the Court to uphold the objection on the grounds that Bank Markazi cannot be characterised as a "company". ${ }^{38}$

\footnotetext{
32 Certain Iranian Assets, para. 91.

33 Now Article 79ter, paragraph 4, following the amendment described in Section 3 above.

34 Certain Iranian Assets, para. 97.

35 Certain Iranian Assets, Joint Separate Opinion of Judges Tomka and Crawford, para. 2.

36 Ibid., paras. 9-10. See the Separate Opinion of Judge ad hoc Brower, para. 24. Judges Tomka and Crawford do not express a view, however, on whether the Court should have upheld the preliminary objection.

37 Certain Iranian Assets, Declaration of Judge Gaja, para. 1.

38 Certain Iranian Assets, Separate Opinion of Judge ad hoc Brower, para. 24.
} 


\subsubsection{Application of the ICSFT and CERD}

Ukraine has instituted proceedings against Russia relying on the compromissory clauses of two treaties: Article 24(1) of the International Convention on the Suppression and Financing of Terrorism (ICSFT) and Article 22 of the International Convention on the Elimination of All Forms of Racial Discrimination (CERD).

Ukraine has invoked the ICSFT to complain about measures adopted by Russia in connection with the conflict taking place in eastern Ukraine, including the destruction of Malaysia Airlines Flight MH17. Russia contended that the Court lacked jurisdiction ratione materiae to hear those claims because the ICSFT did not cover matters of State responsibility for financing terrorism, and because, in any event, Ukraine had failed to show that the financing of terrorism allegedly performed by Russia was qualified with the specific intent or knowledge that triggers the application of the ICSFT.

In its judgment on preliminary objections, the Court rejects Russia's objection. It begins its analysis by noting that "an examination by the Court of the alleged wrongful acts or of the plausibility of the claims is not generally warranted" at the preliminary stage. ${ }^{39}$ Interpreting the provisions of the ICSFT, and also taking into consideration its preparatory work, the Court agrees with Russia that "[ $\mathrm{t}]$ he financing by a State of acts of terrorism is not addressed by the ICSFT". ${ }^{40}$ It finds, however, that the parties to the Convention have undertaken, in Article 2 of the Convention, to "take appropriate measures and to co-operate in the prevention and suppression of offences of financing acts of terrorism committed by whichever person", whether those persons are acting in a private capacity or on behalf of the State. ${ }^{41}$ Therefore, to the extent that the dispute concerns a failure by Russia to prevent and suppress offences committed either by private parties or by its own agents, it falls within the Court's jurisdiction ratione materiae.

As regards the question of whether a specific intent or knowledge to finance acts of terrorism was present, the Court observes that this "raises complex issues of law and especially of fact that divide the Parties and are properly a matter for the merits". ${ }^{42}$ Another issue left for the merits was the interpretation of the term "funds" in the ICSFT, which, the Court notes, had not been the subject of any specific objection by Russia at the preliminary stage. ${ }^{43}$

39 Application of ICSFT and CERD, para. 58.

$40 \quad$ Ibid., para. 59.

41 Ibid., para. 6o.

$42 \quad$ Ibid., para. 63.

$43 \quad$ Ibid., para. 62. 
The Court's rejection of Russia's objection was commented upon by Vice-President Xue, Judges Tomka, Donoghue and Robinson, and Judge ad hoc Skotnikov. A recurring theme was the apparent tension between the finding that the ICSFT does not cover financing of terrorism by States and the finding that the ICSFT nevertheless requires States to prevent and suppress the financing of acts of terrorism performed by their own agents. Agreeing with the majority, Judge Donoghue describes the situation in which the drafters of the Convention "refrained from including a prohibition on State financing of terrorism" but "nonetheless adopted a text that has substantively similar consequences for States parties" as an "odd result". Yet, she observes that the language employed in Article 2 of the Convention, "in its ordinary meaning, admits of no limitation".44 Judge Robinson agrees, but he would have wished the Court to infer from the ICSFT an obligation on the parties themselves not to fund terrorism. In his opinion, the text of the Convention (and Article 2 in particular) would support such an inference, and he criticises the Court for "[putting] the proverbial cart before the horse" when it prematurely concluded that "State financing was outside the scope of the Convention".45

Dissenting from the Court, Vice-President Xue and Judge ad hoc Skotnikov regard the Court's interpretation of Article 2 as incompatible with the finding that State responsibility for financing terrorism does not fall within the scope of the ICSFT. Judge ad hoc Skotnikov notes that "[s]ince a State is an abstract entity, which acts through its officials", the conclusion that the ICSFT does not impose responsibility for State financing of terrorism does not "sit well with the Court's finding ... that the Convention applies both to persons who are acting in a private capacity and those who are State agents." ${ }^{\prime 6}$ For Vice-President Xue, that puts the Court in the untenable position, at the merits stage, of having to deal indirectly with a question that is excluded from its jurisdiction. ${ }^{47}$

Vice-President Xue, Judge Tomka and Judge ad hoc Skotnikov also criticise the majority for not offering an interpretation of the term "funds" employed in the ICSFT. Judge Tomka remarks that "the issue has been left open despite the fact that the legal definition of the term 'funds' for the purposes of the ICSFT is not closely intertwined with the merits". As a result, he believes "the principal task of the jurisdictional stage of the proceedings has not been fully realized".48 In a similar vein, Judge ad hoc Skotnikov admonishes that "this

Application of ICSFT and CERD, Declaration of Judge Donoghue, paras. 19-2O.

45 Application of ICSFT and CERD, Declaration of Judge Robinson, paras. 4-6.

46 Application of ICSFT and CERD, Dissenting Opinion of Judge ad hoc Skotnikov, para. 7 .

47 Application of ICSFT and CERD, Dissenting Opinion of Vice-President Xue, para. 10.

48 Application of ICSFT and CERD, Separate Opinion of Judge Tomka, para. 8. 
preliminary issue relating to the scope of the ICSFT is being transformed, without any justification, into an issue for the merits". ${ }^{9}$

In addition to the ICSFT, Ukraine has invoked CERD to complain of Russia's treatment of Crimean Tatars and ethnic Ukrainians in Crimea. Russia objected to the Court's jurisdiction ratione materiae by arguing that the measures that Ukraine is challenging do not fall within the scope of CERD.

The Court rejects Russia's objection. It notes, first of all, that there is no need to determine, at the preliminary stage of the proceedings, whether the measures challenged by Ukraine constitute racial discrimination or are covered by the provisions of CERD, as that can only be decided after the Court considers "issues of fact, largely depending on evidence regarding the purpose or effect of the measures", which are "properly a matter for the merits". ${ }^{0}$ Instead, the Court finds that "Crimean Tartars and ethnic Ukrainians in Crimea constitute ethnic groups protected under CERD", and that the measures alleged are "capable of having an adverse effect on the enjoyment" of the "broadly formulated" rights protected under the Convention. ${ }^{51}$

Judge ad hoc Skotnikov dissents from the majority, expressing his regret that "the Court failed to consider questions relating to the scope of CERD".52 Judge Tomka also criticises the majority for what he views as a very brief treatment of the detailed argument offered by Russia. But he ultimately votes in favour of rejecting Russia's preliminary objection on the ground that at least some of the claims made by Ukraine fall within the provisions of CERD. ${ }^{53}$

4.1.3 Alleged Violations of the 1955 Treaty of Amity

The second case brought under the compromissory clause in the 1955 Treaty of Amity between Iran and the United States is Alleged Violations of the 1955 Treaty of Amity, Economic Relations, and Consular Rights. Iran instituted proceedings against the United States to complain about certain economic sanctions that the United States reinstated following its withdrawal from the Joint Comprehensive Plan of Action ("JCPOA"), an agreement designed to ensure that Iran's nuclear programme be used for peaceful purposes. Iran argues that by imposing those sanctions the United States finds itself in breach of the Treaty of Amity.

Application of ICSFT and CERD, Dissenting Opinion of Judge ad hoc Skotnikov, para. 6. See also Dissenting Opinion of Vice-President Xue, para. 9 .

50 Application of ICSFT and CERD, para. 94.

$5^{1} \quad$ Ibid., paras. 95-96.

52 Application of ICSFT and CERD, Dissenting Opinion of Judge ad hoc Skotnikov, para. 9.

53 Application of ICSFT and CERD, Separate Opinion of Judge Tomka, paras. 14-15. 
The United States made two objections concerning the Court's jurisdiction ratione materiae, which were unanimously rejected by the Court. The first was that the subject-matter of Iran's claims related to the JCPOA, and not to alleged violations of the Treaty of Amity. The Court dismisses the objection by observing that " $\mathrm{t}]$ he fact that the dispute between the Parties has arisen in connection with and in the context of the decision of the United States to withdraw from the JCPOA does not in itself preclude the dispute from relating to the interpretation or application of the Treaty of Amity".54 That is because any particular conduct may trigger the application of more than one instrument. ${ }^{55}$ The Court notes, in addition, that in determining the subject-matter of a treaty it is not allowed "to modify the object of the submissions, especially when they have been clearly and precisely formulated", or to "infer the subject-matter of a dispute from the political context ... rather than basing itself on what the applicant has requested of it".56

The second objection made by the United States was that most of the measures of which Iran complained were "third country measures", that is, measures concerning trade or transactions between Iran and third countries, or between nationals and companies of Iran and third countries. For the United States, such measures do not fall within the scope of the Treaty of Amity, which would only apply to trade or transactions between the parties or between nationals and companies of the parties. Considering the objection, the Court explains that its task was to look into "whether each of the measures - or category of measures - under consideration is of such a nature as to impair the rights of Iran under the various provisions of the Treaty of Amity which the Applicant claims to have been violated".57 And it finds that such an exercise could only be performed "through a detailed examination of each of the measures in question, of their reach and actual effects".58 As a result, the Court decides that the objection is not preliminary in character, but rather raises "legal and factual questions which are properly a matter for the merits". 59

While voting with the majority, Judge Tomka disagrees that a determination of whether the Treaty of Amity covers "third country measures" should be left to the merits stage of the case. On the one hand, he believes that the point

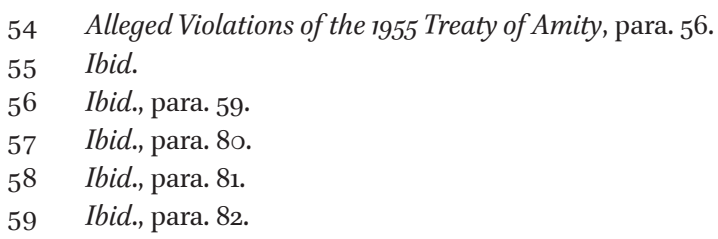


had been sufficiently argued by the parties. ${ }^{60}$ On the other hand, he regards the Court's approach as inconsistent with that taken in the Oil Platforms and Certain Iranian Assets cases, where the Court offered a detailed analysis of provisions from the Treaty of Amity with a view to "inquiring whether the acts complained of were capable of falling within the scope of the provisions invoked by the Applicant". ${ }^{61}$ For Judge Tomka, the Court's characterisation of the question of "third country measures" as one pertaining to the merits ultimately resembles a decision that the objection does not possess an exclusively preliminary character. But with an important difference: if the Court were later to conclude that the Treaty of Amity does not cover "third country measures", that finding would formally constitute a decision on the merits of the dispute, because the Court has definitively rejected the preliminary objection made by the United States. Judge Tomka believes, nevertheless, that the "logical conclusion" from such a finding would be that the Court had lacked jurisdiction ratione materiae to begin with. ${ }^{62}$ That is why such questions of treaty interpretation should always be decided at the preliminary stage.

\subsubsection{Application of CERD}

Article 22 of the Convention on the Elimination of Racial Discrimination was also invoked as a compromissory clause in the Application of CERD case, between Qatar and the United Arab Emirates. Qatar sought to rely on the Convention to complain about the treatment of Qatari nationals, in particular a measure ordering the collective exit of Qatari nationals from the UAE. The UAE made a preliminary objection to the Court's jurisdiction ratione materiae, which the Court upheld by eleven votes to six. ${ }^{63}$

In its judgment, the Court identifies three claims made by Qatar under CERD: (i) a claim "arising out of the 'travel bans' and 'expulsion order" affecting Qatari nationals; (ii) a claim arising from restrictions that the UAE imposed on Qatari media corporations; and (iii) a claim that all those measures "result in 'indirect discrimination' on the basis of Qatari national origin". 64

The Court takes the position that the first claim would only fall within the scope of CERD if CERD prohibited discrimination on the basis of a person's current nationality. In a lengthy passage in the judgment, the Court interprets the phrase "national origin" employed in the Convention and decides that

\footnotetext{
6o Alleged Violations of the 1955 Treaty of Amity, Declaration of Judge Tomka, para. 5 .

61 Ibid., paras. 7-8.

62 Ibid., paras. 11-12.

63 Application of CERD (Qatar v. UAE), paras. 114-115.

64 Ibid., para. 46.
} 
the Convention does not comprise such a prohibition. It draws a distinction between "national origin" and "nationality", concluding that the former is "a person's bond to a national or ethnic group at birth" while the latter "is a legal attribute which is within the discretionary power of the State and can change during a person's lifetime"; observes that the Convention specifically excludes from its purview "distinctions, exclusions, restrictions or preferences ... between citizens and non-citizens" and issues of "nationality, citizenship and naturalization" (Articles 2(2) and 2(3) CERD); states that the object and purpose of CERD to "eliminate all forms and manifestations of racial discrimination against human beings on the basis of real and perceived characteristics of their origin, namely at birth" and to condemn "any attempt to legitimize racial discrimination by invoking the superiority of one social group over another" does not preclude differentiations on the basis of nationality; and finds this reading to be confirmed by the travaux préparatoires of CERD. ${ }^{65}$

Turning to Qatar's second claim, the Court finds that "the Convention concerns only individuals or groups of individuals", and does not extend to media corporations. For the Court, the "institutions" that are protected by CERD pursuant to Article 2(1)(a) are only "collective bodies or associations, which represent individuals or groups of individuals".66

As regards Qatar's third claim, based on the notion of "indirect discrimination", the Court accepts that "the Convention prohibits all forms and manifestations of racial discrimination, whether arising from the purpose of a given restriction or from its effect". ${ }^{67}$ It also recognises that the measures that Qatar has complained of "may have collateral or secondary effects on persons born in Qatar or of Qatari parents, or on family members of Qatari citizens residing in the UAE" ${ }^{68}$ It concludes, however, that those collateral or secondary effects do not constitute racial discrimination. In the words of the Court, "the various measures of which Qatar complains do not, either by their purpose or by their effect, give rise to racial discrimination within the meaning of CERD". 69

The Court's assessment of Qatar's third claim was the point that attracted the greatest amount of criticism from dissenting judges. President Yusuf and

65 Ibid., paras. 81-88; 92-97. In their respective dissenting opinions, Judges Bandhari and Robinson engage and disagree with the majority's interpretation of "national origin": Application of CERD (Qatar v. UAE), Dissenting Opinion of Judge Bhandari, paras. 10-2O; and Dissenting Opinion of Judge Robinson, paras. 7-12.

66 Application of CERD (Qatar V. UAE), para. 108.

$67 \quad$ Ibid., para. 112.

68 Ibid.

69 Ibid. 
Judges Sebutinde, Robinson and Iwasawa all thought that the Court's decision that the measures alleged by Qatar did not constitute indirect discrimination involved a determination of fact that should have been reserved for the merits phase of the proceedings..$^{70}$ In the words of Judge Sebutinde, there is "a thin line between 'Qatari national origin' and 'Qatari nationality or citizenship', a line that was "particularly blurred by the circumstances of the case". ${ }^{71}$ The judges also accuse the majority of deviating from the approach taken just a few months earlier in the Application of ICSFT and CERD case, where the Court decided that a determination of whether racial discrimination had been committed was not required to assert jurisdiction ratione materiae, the test being simply whether the conduct alleged was "capable of having an adverse effect on the enjoyment of certain rights protected under CERD". ${ }^{72}$

President Yusuf also offers a broader critique of the Court's handling of Qatar's claims. To his mind, "the majority frames the subject-matter of the dispute in a manner totally disconnected from the Applicant's written and oral pleadings" given that Qatar maintains that the UEA is engaging in discrimination on the basis of national origin instead of current nationality. ${ }^{73}$ By doing so, the Court would be deviating from its "long-standing jurisprudence" of determining "on an objective basis the subject-matter of the dispute between the Parties, 'while giving particular attention to the formulation of the dispute chosen by the applicant"."74

\subsubsection{Thoughts on Recent Judgments on Jurisdiction ratione materiae}

Each of the judgments that the ICJ rendered on jurisdiction ratione materiae in the period reported has its own particularities and deserves to be examined individually. But comparing them is illuminating insofar as it shows the Court grappling with the task of determining whether a dispute falls within the scope of a treaty when faced with the creative and sophisticated submissions of the parties. While the Court has been consistent in its description of the test to be applied, its approach in applying that test has been patchier,

70 Application of CERD (Qatar v. UAE), Declaration of President Yusuf, paras. 13-16; Dissenting Opinion of Judge Sebutinde, paras. 19-20; Dissenting Opinion of Judge Robinson, para. 27; Separate Opinion of Judge Iwasawa, paras. 61-69. Judge Iwasawa would have wished the Court to declare the issue as not possessing an exclusively preliminary character under Rule 79ter (4) of the Rules of Court (at para. 70).

71 Application of CERD (Qatarv. UAE), Dissenting Opinion of Judge Sebutinde, para. 20.

72 Application of CERD (Qatar v. UAE), Declaration of President Yusuf, para. 17; Dissenting Opinion of Judge Sebutinde, para. 19; Separate Opinion of Judge Iwasawa, para. 67.

73 Application of CERD (Qatarv. UAE), Declaration of President Yusuf, para. 6.

74 Ibid., para. 10. 
as judges writing individual opinions were quick to highlight. So, for example, while the Court is accused of holding back by not offering interpretations of certain treaty provisions in Certain Iranian Assets, Application of the ICSFT and CERD and Alleged Violations of the 1955 Treaty of Amity, it is criticised for adopting too categorical a position on "indirect discrimination" in Application of CERD.

It has become increasingly clear that in cases brought under the compromissory clause of a specific treaty the Court is expected to form a definitive view on all issues of interpretation that would have the effect of excluding the dispute from the purview of the treaty. That can make the line between questions of jurisdiction and questions of merit look particularly blurry. As Judge Donoghue suggests in her Declaration in Application of the ICSFT and CERD, the distinction between treaty interpretation as a jurisdictional question and treaty interpretation as a question of merit is important, but there is "no single phrase that neatly describes the boundary between the two". ${ }^{75}$ That is why the distinction has to be "drawn by the Court, informed by the positions of the parties, based on the particulars of each case". 6 "The way that [the Court] expresses its conclusions about the interpretation of the treaty", Judge Donoghue adds, "will inevitably vary depending on the particulars of the case". ${ }^{77}$

While Judge Donoghue's remarks help explain inconsistencies between cases, and even make some of them look more apparent than real, she only scratches the surface of a fascinating albeit elusive question: what are the judicial sensibilities that lead the Court to draw the line slightly differently as it moves from case to case? In her Dissenting Opinion in Application of the ICSFT and CERD, Vice-President Xue suggests that "[j]udicial policy requires the Court to avoid unnecessary prolongation of the legal process if the case does not present itself as plausible". ${ }^{78}$ Considerations of judicial economy are indeed one of the factors that may have a role in helping the Court decide whether a claim should proceed to the merits stage in borderline cases.

It is perhaps useful to remember, in this connection, that there is little difference between a judgment declining jurisdiction ratione materiae and a judgment on the merits where it is decided that the treaty in question has not been breached. When the Court decides that it lacks jurisdiction ratione personae or ratione temporis, or that a procedural precondition has not been met, or that a claim is inadmissible, the question of how the treaty applies

75 Application of ICSFT and CERD, Declaration of Judge Donoghue, para. 3.

76 Ibid.

77 Ibid., para. 10.

78 Application of ICSFT and CERD, Dissenting Opinion of Vice-President Xue, para. 11. 
to the facts is left unresolved. In contrast, it follows from a rejection of jurisdiction ratione materiae that the acts allegedly committed do not violate the treaty invoked. The dispute between the parties under the treaty is thus ultimately settled. In such cases, then, the stakes for the Court are twofold: to show to the parties that it is mindful of the limits of its own competence, and to ensure that the parties are given every reasonable opportunity to be heard. How the Court strikes a balance between those two goals may well vary depending on the circumstances of every case.

\subsection{Procedural Preconditions in Compromissory Clauses}

Compromissory clauses often comprise "procedural preconditions" that have to be met before consent to having a dispute under a treaty settled by the ICJ is deemed to have been given by the parties. Among the judgments rendered in the period reported, three involved challenges to the Court's jurisdiction based on the alleged non-fulfilment of procedural preconditions. ${ }^{79}$ The discussion below covers the decisions and controversy relating to each individual compromissory clause that the Court examined.

4.2 .1

Article IV, 1966 Geneva Agreement Between Guyana and Venezuela

Guyana has commenced proceedings against Venezuela with a view to settling a dispute revolving around Venezuela's contention that the Arbitral Award of 3 October 1899, which delimits the boundary between the two States, is null and void. It has invoked the compromissory clause found in Article IV of the 1966 Agreement to Resolve the Controversy between Venezuela and the United Kingdom of Great Britain [Guyana's predecessor] and Northern Ireland over the Frontier between Venezuela and British Guiana. The so-called "Geneva Agreement" is somewhat peculiar. It envisages the establishment of a Mixed Commission "with the task of seeking satisfactory solutions for the practical settlement" of the dispute revolving around the boundary between Venezuela and Guyana (Article I). It stipulates, in Article IV(1), that if the Mixed Commission fails to arrive at a "full agreement for the solution of the controversy it shall ... refer to the Government of Guyana and the Government of Venezuela any outstanding questions", to be solved by recourse to "one of the means of peaceful settlement provided for in Article 33 of the Charter of the United Nations". Article $\operatorname{IV}(2)$ then prescribes that if the parties

79 Procedural preconditions neither posed a problem in the cases concerning Certain Iranian Assets and Alleged Violations of the 1955 Treaty of Amity, between Iran and the United States, nor in the Jadhav case, opposing India and Pakistan. 
fail to reach an agreement on a mode of dispute settlement within three months they:

shall refer the decision as to the means of settlement to an appropriate international organ upon which they both agree or, failing agreement on this point, to the Secretary-General of the United Nations. If the means so chosen do not lead to a solution of the controversy, the said organ or, as the case may be, the Secretary-General of the United Nations shall choose another of the means stipulated in Article 33 of the Charter of the United Nations, and so on until the controversy has been resolved or until all the means of peaceful settlement there contemplated have been exhausted. ${ }^{80}$

By the time Guyana brought the case, a Mixed Commission had been constituted and failed to reach agreement on a solution to the dispute. The parties had been unable to agree on a means of dispute settlement, and the UN Secretary-General had directed them to resort to good offices. Good offices had been unsuccessfully attempted for over two decades, leading the current Secretary-General, António Guterres, to recommend that the dispute be submitted to judicial settlement by the ICJ. ${ }^{81}$

In a memorandum shared with the Court, Venezuela expresses its objection to the Court's jurisdiction on the grounds that it has not expressed its consent to having the dispute adjudicated. In its judgment on jurisdiction, the Court dismisses this objection on the basis of six findings.

First, that "the 'controversy' that the parties agreed to settle through the mechanism established under the Geneva Agreement concerns the question of the validity of the 1899 Award, as well as its legal implications for the boundary line between Guyana and Venezuela". ${ }^{2}$ The dispute could thus fall under the jurisdiction ratione materiae of the Court.

Second, that the parties "conferred on the Secretary-General the authority to choose, by a decision which is binding on them, the means to be used for the settlement of their controversy". ${ }^{83}$ This conclusion was reached on the basis of the ordinary meaning of the terms employed in Article IV(2) (in particular, the words "shall", "refer" and "decision") and of the object and purpose of the

80 Text quoted in Arbitral Award of 3 October 1899 (Guyana v. Venezuela), Judgment of 18 December 2020, para. 61.

81 See Arbitral Award of 3 October 1899, paras. 29-6o.

82 Ibid., para. 66.

83 Ibid., para. 74 . 
Geneva Agreement (described by the Court as that of "ensuring a definitive resolution of the controversy between the Parties"). ${ }^{84}$

Third, that through Article IV of the Geneva Agreement the parties have "accepted the possibility" of recourse to judicial settlement as a means to settle their dispute. ${ }^{85}$ That was because Article IV makes reference to Article 33 of the UN Charter, which includes judicial settlement as a means for the peaceful settlement of disputes. For the Court, had the parties wished to exclude judicial settlement, they would have done that expressly, for example by specifying which of the means envisaged by Article 33 could be resorted to. ${ }^{86}$ The Court does not think that the somewhat confusing tail end of $\operatorname{Article~IV(2),~where~it~}$ is envisaged that the Secretary-General shall exercise his or her powers "until the controversy has been resolved or until all the means of peaceful settlement there contemplated have been exhausted", reflects the parties' intention to exclude recourse to modes of settlement that would resolve the dispute once and for all (such as judicial settlement). Rather, it points out that there are "various reasons why a judicial decision, which has the force of res judicata and clarifies the rights and obligations of the parties, might not in fact lead to the final settlement of a dispute". ${ }^{87}$ The Court thus seemingly suggests that Article IV(2) is a mere recognition of the possibility that judicial settlement may not resolve a dispute, as when one of the parties refuses to comply with the binding judgment and the controversy thus endures.

Fourth, that "the Secretary-General was not required to follow the order in which the means of settlement are listed in Article 33 of the Charter but instead had the authority to give preference to one means over another". ${ }^{88}$ The Court makes the finding on the basis of the ordinary meaning of $\operatorname{Article~} \operatorname{IV}(2)$, the object and purpose of the Geneva Agreement and the subsequent practice of the parties.

Fifth, that the decision of Secretary-General Guterres to choose judicial settlement by the International Court of Justice was made in accordance with Article IV(2), seeing that the means of peaceful settlement originally chosen (good offices) had not led to a resolution of the controversy. ${ }^{89}$

Sixth, that Guyana and Venezuela have consented to the jurisdiction of the Court to settle the dispute by "conferring on the Secretary-General the authority to choose the appropriate means of settlement of the controversy, including

\footnotetext{
$84 \quad$ Ibid., paras. $73^{-74}$.

85 Ibid., para. 82 .

86 Ibid.

$87 \quad$ Ibid., para. 86.

88 Ibid., para. 99.

$89 \quad$ Ibid., paras. 103-109.
} 
the possibility of recourse" to the ICJ. ${ }^{90}$ The Court reiterates that its jurisdiction is based on the consent of the parties, and that "an unequivocal indication of the desire of the parties to a dispute to accept the jurisdiction of the Court in a voluntary and indisputable manner" is required. ${ }^{91}$ At the same time, it emphasises that the parties are at liberty to express their consent in whatever form they choose, including through a mechanism such as that envisaged in Article IV(2) of the Geneva Agreement. ${ }^{92}$ The Court thus dismisses the contention that it would only have jurisdiction if the parties were to proceed to implement the decision of the Secretary-General by specifically consenting to taking the dispute to the ICJ. It rules that the decision of the Secretary-General to choose judicial settlement is sufficient because the authority conferred upon the Secretary-General under Article $\operatorname{IV}(2)$ "would not be effective ... if it were subject to the further consent of the Parties for its implementation". 93

The Court's decision to assert jurisdiction over the dispute between Guyana and Venezuela was made by twelve votes to four. The four dissenting judges took special issue with the Court's sixth finding. Judge Gaja agrees with the majority that a valid decision by the Secretary-General under Article IV(2) of the Geneva Agreement creates an obligation for the parties to have recourse to judicial settlement by the ICJ. ${ }^{94}$ However, he expresses the view that the Court can only exercise jurisdiction once the parties actually fulfil that obligation by expressing their respective consent. ${ }^{95}$ Taking an even more critical approach, Judge Bennouna finds no precedent in international practice "in which States can be said to have delegated to a third party, such as the Secretary-General, their power to consent to the Court's jurisdiction", and notes that what makes the Court's approach particularly problematic is that "[i]t would open the possibility for the Secretary-General of the United Nations, simply by letter and at any time, to affirm the Parties' consent for their dispute to be submitted to the Court merely at the request of one of them". ${ }^{96}$

Judges Bennouna, Abraham and Gevorgian also disagree with the reasoning that the majority offers in support of the third finding described above. Judge Bennouna criticises the Court for not allowing the tail end of Article IV(2) "to produce fully [its] effects". ${ }^{97}$ Judge Gevorgian fleshes that point out when

\footnotetext{
$90 \quad$ Ibid., para. 115 .

$91 \quad$ Ibid., paras. 111 and 113.

$92 \quad$ Ibid., para. 112.

93 Ibid., para. 114.

94 Arbitral Award of 3 October 1899, Declaration of Judge Gaja, para. 2.

95 Ibid., paras. $3-5$.

96 Arbitral Award of 3 October 1899, Dissenting Opinion of Judge Bennouna, para. 11.

$97 \quad$ Ibid., para. 8.
} 
he says that "Article $\operatorname{IV}(2)$ is better interpreted as requiring agreement by the Parties before the Secretary-General's choice of the means of settlement may be implemented", for that "would explain how the Secretary-General's choice of a binding means such as judicial settlement could leave the controversy unresolved, namely by allowing for the possibility that the Parties would fail to agree on the implementation of the Secretary-General's choice". ${ }^{98}$ For Judge Gevorgian, "the Geneva Agreement's true object and purpose is to assist the Parties in reaching an agreed resolution of the present dispute" and "the Secretary-General's role could be conceived of as similar to that of a conciliator entrusted with helping the Parties reach an agreed solution to the dispute rather than imposing a means of settlement on them". 99

The Court's substantiation of the third finding is also criticised by Judge Robinson, who, however, takes a very different perspective to that of the dissenting judges. To his mind, the argument that "the Secretary-General may have recourse to all the means of settlement set out in Article 33 without the dispute being resolved" is "fallacious", given that both arbitration and judicial settlement are "capable of definitively resolving the dispute". ${ }^{100} \mathrm{He}$ would thus have preferred the Court to have declared that the Secretary-General's choice of judicial settlement had rendered the tail end of Article IV(2) "inoperative" and with "no practical consequences in the circumstances of this case". ${ }^{101}$

The Court's decision on what might at first glance seem like a rather technical case thus raises some fundamental questions. Judges Bennouna and Gevorgian are particularly emphatic in their criticism that the Court is departing from the principle of consent that underpins its contentious jurisdiction under Article 36 of the ICJ Statute. In Judge Bennouna's words, "only through a rigorous interpretation of the consent of the Parties to its jurisdiction that the Court will enhance its own credibility and the trust it enjoys among States parties to the Statute".102 Judge Gevorgian, on his part, suggests that "[r]ather than basing itself upon an unequivocal, indisputable indication of Venezuela's consent, as its jurisprudence requires, the Court goes looking for reasons to exercise jurisdiction, relying in particular on the presumed intentions of the Parties and upon a series of statements that are, at best, of ambiguous meaning". 103 That approach, he thinks, is not only "wrong" but also "under-

98 Arbitral Award of 3 October 1899, Dissenting Opinion of Judge Gevorgian, para. 14. A similar point is made in the Dissenting Opinion of Judge Abraham, paras. 17-18.

99 Ibid., para. 11.

100 Arbitral Award of 3 October 1899, Separate Opinion of Judge Robinson, para. 12.

101 Ibid.

102 Arbitral Award of 3 October 1899, Dissenting Opinion of Judge Bennouna, para. 13.

103 Arbitral Award of 3 October 1899, Dissenting Opinion of Judge Gevorgian, para. 29. 
mines the fundamental principle of consent by the parties to the jurisdiction of the Court". 104

While the concerns of the judges are perfectly understandable, it is important to acknowledge how odd the compromissory clause that the Court had to construe was. The procedure that the parties agreed to is so unusual, and the drafting of the tail end of Article IV(2) is so puzzling, that one can hardly fault the Court for resolving the contradiction in the way that best allows the Geneva Agreement's object and purpose to be fulfilled. Although it may be plausible to suppose that the parties would have wished to retain a final say (or a veto) on the means of dispute settlement to be pursued, one would have expected them to make this option clear instead of agreeing to refer "the decision as to the means of settlement" to a third party. The lesson to be extracted is that the drafters of dispute settlement treaties and compromissory clauses should seek to reach the greatest level of clarity and precision possible, without ever assuming that the Court will see ambiguities or contradictions in the text as reasons to decline jurisdiction. ${ }^{105}$

\subsubsection{Article 22 CERD}

The compromissory clause in the Convention on the Elimination of All Forms of Racial Discrimination is to be found in Article 22, which provides that:

Any dispute between two or more States Parties with respect to the interpretation or application of this Convention [CERD], which is not settled by negotiation or by the procedures expressly provided for in this Convention, shall, at the request of any of the parties to the dispute, be referred to the International Court of Justice for decision, unless the disputants agree to another mode of settlement.

Article 22 was extensively discussed in the judgment on preliminary objections that the Court gave in the Georgia v. Russia case in 2011. The Court construed the phrase "which is not settled by negotiation" as an operative procedural precondition for its exercising jurisdiction over a dispute under CERD, noting,

104 Ibid.

105 In the Free Zones of Upper Savoy and the District of Gex case, the Permanent Court of International Justice stated that "in case of doubt the clauses of a special agreement by which a dispute is referred to the Court, must, if it does not involve doing violence to their terms, be construed in a manner enabling the clauses themselves to have appropriate effects" (Order of 19 August 1929, P.C.I.J., Series A, No. 22, p. 13). 
inter alia, that those words had to be given effect. ${ }^{106}$ It observed that negotiations presupposed a "genuine attempt by one of the disputing parties to engage in discussions with the other disputing party, with a view to resolving the dispute", and that "the precondition of negotiation is met only when there has been a failure of negotiations, or when negotiations have become futile or deadlocked". ${ }^{107}$ The Court added that "the subject-matter of the negotiations must relate to the subject-matter of the dispute which, in turn, must concern the substantive obligations contained in the treaty" comprising the compromissory clause. ${ }^{108}$ On the facts, the Court found that Georgia had not made a genuine attempt to negotiate its dispute under CERD with Russia, and that Russia had not thus given its consent to the Court's jurisdiction. ${ }^{109}$

It would seem that Ukraine had learned its lesson from Georgia's experience when it brought before the Court its claims under CERD in the Application of the ICSFT and CERD case. Having heard Russia's preliminary objection that Ukraine failed to fulfil the negotiation precondition in Article 22, the Court finds that "the negotiations between the Parties lasted for approximately two years and included both diplomatic correspondence and face-to-face meetings, which, in the Court's view ... indicates that a genuine attempt at negotiation was made by Ukraine". ${ }^{110}$ It also rules that "the negotiations between the Parties had become futile or deadlocked" by the time Ukraine instituted proceedings, as neither of the parties had changed their position during their diplomatic exchanges. ${ }^{111}$ As a result, the Court holds that Ukraine has fulfilled the negotiation precondition.

But what is most interesting about the Court's judgment in Application of the ICSFT and CERD is that it deals with an issue that had been reserved in Georgia v. Russia: ${ }^{12}$ the question of whether the elements of the precondition that the dispute be "not settled by negotiation or by the procedures expressly provided for" in CERD are alternative or cumulative. Siding with Ukraine, the Court finds those elements to be alternative, that is, that a party to the

106 Application of the International Convention on the Elimination of All Forms of Racial Discrimination (Georgia v. Russian Federation), Preliminary Objections, Judgment, I.C.J. Reports 2011, para. 133 (discussed in Editorial Staff, "Procedural Developments at the International Court of Justice", 10 The Law and Practice of International Courts and Tribunals (2011), 507, 532-556).

107 Ibid., paras. 157 and 159 .

108 Ibid., para. 161.

109 Ibid., para. 182.

110 Application of the ICSFT and CERD, para. 120.

111 Ibid.

112 Georgia v. Russia, para. 183. 
Convention which has unsuccessfully either pursued negotiations or resorted to the CERD procedures is entitled to bring the dispute before the Court.

While conceding that the ordinary meaning of the terms employed in Article 22 is compatible with both interpretations, ${ }^{113}$ the Court finds that both the context of Article 22 and the object and purpose of CERD militate against seeing those elements as cumulative. On the one hand, that is because they are both "means to achieve the same objective, namely to settle a dispute by agreement" and "it would not be reasonable to require States parties which have already failed to reach an agreed settlement through negotiations to engage in an additional set of negotiations" following recourse to the Convention's procedures. ${ }^{114}$ On the other hand, the achievement of the Convention's "aim to eradicate all forms of racial discrimination effectively and promptly ... could be rendered more difficult if the procedural preconditions under Article 22 were cumulative". 115 The Court did not consider it necessary to examine the travaux préparatoires of CERD to confirm its interpretation of Article 22. ${ }^{116}$

Judge Tomka and Judge ad hoc Skotnikov criticise the Court's finding in their respective individual opinions. Judge ad hoc Skotnikov contends that the Court "conflates negotiation and conciliation, which are distinct modes of dispute settlement". ${ }^{17}$ Judge Tomka is convinced that both a textual and a contextual interpretation of Article 22, supported by the practice of the parties to CERD, militate in favour of finding the elements of negotiation and CERD procedures as being cumulative instead of alternative. ${ }^{118}$ Both judges express surprise at the Court's decision not to look into the preparatory work of CERD. Judge Tomka describes that as a "spectacular' turn-around" from the Court's previous judgments concerning CERD. ${ }^{119}$ For Judge ad hoc Skotnikov, "[t]his incongruity is best explained by the fact that recourse to the travaux

\footnotetext{
113 Application of the ICSFT and CERD, para. 107.

114 Ibid., para. 110.

115 Ibid., para. 111. Writing in support of the majority's opinion, Judge Cançado Trindade observes that "the approach (of alternatives) adopted by the ICJ in the cas d'espèce is confirmed by the nature and substance of the CERD Convention, a victim-oriented human rights treaty", "that a compromissory clause such as that of Article 22 of the CERD Convention is directly related to [the victims'] access to justice" and that, as a result, a "strict State-centered voluntarist perspective, and a recurring search for State 'consent" would not be appropriate: Application of the ICSFT and CERD, Separate Opinion of Judge Cançado Trindade, paras. 20 and 26.

116 Ibid., para. 112.

117 Application of the ICSFT and CERD, Dissenting Opinion of Judge ad hoc Skotnikov, para. 13.

118 Application of the ICSFT and CERD, Separate Opinion of Judge Tomka, paras. 22-27.

119 Ibid., para. 27.
} 
would, in this instance, serve to undermine rather than to confirm the Court's conclusion". 120

Unlike Judge ad hoc Skotnikov, Judge Tomka ultimately voted with the majority on the grounds that, in the circumstances of the case, recourse to CERD procedures would be a "futile exercise" and that requiring Ukraine to refer the dispute to the CERD Committee "would have been an exercise in excessive formalism". ${ }^{21} \mathrm{He}$ observes that "[e]ven if the Application was premature, this defect could have been remedied by the Applicant and it would make no sense to require Ukraine to institute fresh proceedings". ${ }^{122}$ While there is much to commend in Judge Tomka's suggestion that the Court should refrain from engaging in excessive procedural formalism, his approach is at odds with recent judgments where jurisdiction was declined even when procedural defects had been cured during the proceedings themselves, most notably the Court's judgments in the Marshall Islands cases. ${ }^{123}$

In the proceedings of the Application of CERD case, the UAE also made a preliminary objection arguing that the Court lacked jurisdiction because the procedural preconditions of Article 22 of CERD, which the UAE also viewed as cumulative, had not been met. The difference between the two cases, though, was that Qatar had referred the dispute to the CERD Committee prior to bringing its claim before the Court, so that, by the time the Court gave its judgment on preliminary objections, the complaint before the CERD Committee was still pending. That raised not only the question of whether the elements in Article 22 were cumulative or alternative, but also the question of whether the Court should assert jurisdiction in parallel with the CERD Committee. Because the Court concluded, as reported above, that it lacked jurisdiction ratione materiae over the claims made by Qatar, it refrained from examining the UAE's objection based on procedural preconditions. ${ }^{124}$ But both Judge Sebutinde and Judge ad hoc Daudet made a point to emphasise, in their individual opinions, that procedural preconditions would pose no obstacle to the Court exercising jurisdiction in that case. Judge Sebutinde refers to the "fundamentally distinct

\footnotetext{
120 Application of the ICSFT and CERD, Dissenting Opinion of Judge ad hoc Skotnikov, para. 13.

121 Application of the ICSFT and CERD, Separate Opinion of Judge Tomka, para. 3 .

122 Ibid.

123 Obligations concerning Negotiations relating to Cessation of the Nuclear Arms Race and to Nuclear Disarmament (Marshall Islands v. United Kingdom), Preliminary Objections, Judgment, I.C.J. Reports 2016 (discussed in Bordin, "Procedural Developments at the International Court of Justice", 17 The Law and Practice of International Courts and Tribunals (2017), 307, 317-323).

124 Application of CERD (Qatar V. UAE), para. 114.
} 
roles" of the CERD Committee and the ICJ in settling disputes, the former "conciliatory and recommendatory", the latter "legal and binding". ${ }^{125}$ As a result, she sees "nothing incompatible about Qatar pursuing the two procedures in parallel". 126

\subsubsection{Article 24(1) ICSFT}

In the judgment on preliminary objections in the Application of the ICSFT and CERD case, the Court also had the occasion to comment on the procedural preconditions found in Article 24(1) of the ICSFT, which reads as follows:

Any dispute between two or more States Parties concerning the interpretation or application of this Convention [ICSFT] which cannot be settled through negotiation within a reasonable time shall, at the request of one of them, be submitted to arbitration. If, within six months from the date of the request for arbitration, the parties are unable to agree on the organization of the arbitration, any one of those parties may refer the dispute to the International Court of Justice, by application, in conformity with the Statute of the Court.

The Court construes the negotiations precondition in the same way as it construed Article 22 of CERD, while noting the specific language that refers to negotiations being held "within a reasonable time". ${ }^{127} \mathrm{On}$ the facts, it finds that Ukraine sought to start negotiations with Russia in 2014, ${ }^{128}$ but that "little progress" had been made. The Court thus concludes that "the dispute could not be settled through negotiation in what has to be considered as a reasonable time and that the first precondition is accordingly met". ${ }^{\prime 29}$

Examining the record, the Court also finds that the second precondition in Article 24(1) - that the parties be unable to agree on the organization of an arbitration within a six-month period following a request for that purpose was also met. ${ }^{130}$

\subsection{Expert Opinions}

Pursuant to Article 5O of the ICJ Statute, the Court "may, at any time, entrust any individual, body, bureau, commission, or other organization that it may

\footnotetext{
125 Application of CERD (Qatar v. UAE), Dissenting Opinion of Judge Sebutinde, para. 32.

126 Ibid. See also Declaration of Judge ad hoc Daudet, para. 4.

127 Application of the ICSFT and CERD, para. 69.

128 Ibid., para. 70.

129 Ibid.

130 Ibid., paras. $76-77$.
} 
select, with the task of carrying out an enquiry or giving an expert opinion".131 This provision is invoked in the Order of 8 September 2020 in the Armed Activities on the Territory of the Congo case, where the Court decides to obtain "an expert opinion" from "four independent experts" to help it quantify damages relating to loss of human life, loss of natural resources and property damage sustained by the Democratic Republic of the Congo. ${ }^{132}$ In a subsequent Order on 12 October 2020, the Court proceeds to appoint said experts. ${ }^{133}$

Those were the latest developments in a case that has been on the ICJ's docket for a long period of time. In its merits judgment of 19 December 2005, the Court found that Uganda "is under obligation to make reparation to the Democratic Republic of the Congo for the injury caused" in the context of its military activities in Congolese territory, and that "failing agreement between the Parties, the question of reparation due to the Democratic Republic of the Congo shall be settled by the Court".134 The parties have been unable to agree on compensation, and the Court's decision to appoint experts, followed by the scheduling of hearings for April 2021, ${ }^{135}$ indicates that it is finally getting ready to rule on the matter. In his Separate Opinion to the Order of 8 September 2020, Judge Cançado Trindade highlights that the determination of compensation "could and should have been made a long time ago". ${ }^{136} \mathrm{He}$ reproaches the majority for repeatedly postponing the oral hearings on reparations, and says that he has "always been of the understanding that attention to the prolonged suffering of numerous victims stands well above attention to susceptibilities of contending States". ${ }^{137}$

In the Order of 8 September 2020, the Court explains its power under Article $5 \mathrm{O}$ of the ICJ Statute and deals with Uganda's objections to the appointment of experts. It affirms that a decision to ask for an expert opinion "in no

131 Also, Art. 67, Rules of Court: "1. If the Court considers it necessary to arrange for an enquiry or an expert opinion, it shall, after hearing the parties, issue an order to this effect, defining the subject of the enquiry or expert opinion, stating the number and mode of appointment of the persons to hold the enquiry or of the experts, and laying down the procedure to be followed. Where appropriate, the Court shall require persons appointed to carry out an enquiry, or to give an expert opinion, to make a solemn declaration. 2. Every report or record of an enquiry and every expert opinion shall be communicated to the parties, which shall be given the opportunity of commenting upon it."

132 Armed Activities on the Territory of the Congo, Order of 8 September 2020, para. 16.

133 Armed Activities on the Territory of the Congo, Order of 12 December 2020.

134 Armed Activities on the Territory of the Congo (Democratic Republic of the Congo v. Uganda), Judgment, I.C.J. Reports 2005, para. 345 .

135 I.C.J. Press Release 2021/14, 29 March 2021.

136 Order of 8 September 2020, Separate Opinion of Judge Cançado Trindade, para. 11.

137 Ibid., para. 16. 
way prejudges the amount of the reparation due by either party to the other, nor any other question relating to the dispute brought before the Court"; that it "leaves intact the parties' right to adduce evidence and submit their arguments on those subjects"; and that "the relevant provisions of the Statute and the Rules of Court safeguard the procedural rights of both Parties when it arranges for an expert opinion", including by allowing the parties to examine the experts in the course of oral hearings. ${ }^{138}$ At the end of the Order, the Court adopts terms of reference outlining the questions to be submitted to the experts. ${ }^{139}$

The Court's Order is criticised by Judge Sebutinde, who does not think that the matter of reparations between the Democratic Republic of the Congo and Uganda involves "complex issues' that require technical, scientific or specialized knowledge or expertise that is outside the realm of normal judicial expertise". Rather, she contends that it is incumbent on the Court to "perform its judicial function by examining the evidence already on record and determining the reparations due". 140

Judge Sebutinde's Dissenting Opinion discusses all the previous cases in which the ICJ exercised it power under Article 50 of the Statute, which she distinguishes from the dispute over reparations pending between the Democratic Republic of the Congo and Uganda. ${ }^{141}$ On the basis of her analysis of the case law, Judge Sebutinde suggests that any decision to enlist experts has to meet seven minimum parameters:

(a) [that] the Court resorts to appointing experts only in 'complex cases' requiring technical, scientific or specialized knowledge or expertise that is outside the realm of normal judicial expertise; (b) that the role of Court-appointed experts is limited to providing specialized information or insight into the scientific or technical intricacies of the evidence already submitted by the parties and that their input should not interfere with the allocation of the burden of proof or tilt the balance in favour of one party or the other; (c) that the ultimate task of discharging the judicial function rests with the Court, and must not be delegated to the experts; (d) that prior consultations between the Court and the concerned parties (concerning the identity of the experts and their terms of reference) are held and, as far as possible, the consent (through a compromis) or at least acquiescence of both parties is obtained before the appointment

${ }_{13} 8$ Order of 8 September 2020, paras. 13-14.

139 Ibid., para. 16.

140 Order of 8 September 2020, Dissenting Opinion of Judge Sebutinde, para. 1.

141 Ibid., paras. 8-14. 
of the experts; (e) that the experts appointed by the Court are neutral; (f) that the experts' reports are availed to the parties for their comment; and $(\mathrm{g})$ that the parties are availed every opportunity to put questions to the experts, before the Court makes its conclusions. ${ }^{142}$

For Judge Sebutinde, the terms of reference found in the Court's Order fail to meet parameters (b) and (c). She believes that those terms have the effect of "unfairly assisting the DRC in augmenting its claim and unfairly buttressing its evidence where it may be wanting, contrary to the principles of a fair hearing and equality of arms", or, in the alternative, of "inappropriately delegating the judicial function to the experts". ${ }^{143}$

\subsection{Non-Appearance}

Venezuela decided not to participate in the preliminary stage of the Arbitral Award of 3 October 1899 case. In its judgment on preliminary objections, the ICJ expresses regret for that decision and observes that "[t]he non-appearance of a party obviously has an impact on the sound administration of justice".144 It notes that, be that as it may, "non-participation of a party in the proceedings at any stage of the case cannot, in any circumstances, affect the validity of its judgment". 145

Non-appearance by a party triggers the application of Article 53 of the ICJ Statute, which allows the other party to "call upon the Court to decide in favour of its claim" while requiring the Court to "satisfy itself, not only that it has jurisdiction ... but also that the claim is well founded in fact and law". According to the Court, the "intention" of this provision is that "neither party should be placed at a disadvantage", which means that the applicant is not entitled to a judgment in its favour and the respondent "cannot be permitted to profit from its [own] absence". 146 In compliance with Article 53, the Court takes into account a memorandum which Venezuela submitted outlining its legal position. ${ }^{147}$

\footnotetext{
142 Ibid., para. 14.

143 Ibid., para. 17. See also the analysis in paras. 18-20.

144 Arbitral Award of 3 October 1899, paras. 24-25.

145 Ibid., para. 26.

146 Ibid., para. 27.

147 Ibid., para. 28.
} 


\subsection{Abuse of Process and "Clean Hands" Doctrine}

Objections to the admissibility of claims based on the notions of abuse of process and abuse of rights have become more common in recent years. In the judgment on preliminary objections in the Immunities and Criminal Proceedings case, the ICJ had the occasion to explain that while abuse of process can be pleaded as a matter of admissibility, abuse of rights is a question for the merits stage. The Court also found that a plea of abuse of process requires "clear evidence" and is only available "in exceptional circumstances". 14

In the period reported, claims of abuse of process were rejected in the Certain Iranian Assets, Jadhav and Alleged Violations of the 1955 Treaty of Amity cases. Interestingly, some of those claims were made together with an argument that has long been a staple of the Philip C. Jessup International Law Moot Court Competition: the "clean hands" doctrine.

In Certain Iranian Assets, the United States argued that Iran's claims were an abuse of process because, among other things, Iran was not seeking to vindicate its rights under the Treaty of Amity but rather "to embroil the Court in a broader strategic dispute". ${ }^{149}$ It also argued that Iran appeared before the Court with "unclean hands" because it had been a sponsor of terrorism who should not be entitled to complain about sanctions imposed as a result of its own unlawful actions. ${ }^{150}$ As regards abuse of process, the Court merely notes that there are no "exceptional circumstances" justifying its declining jurisdiction. ${ }^{151}$ As regards the "clean hands" doctrine, it first notes that the United States did not argue that Iran had violated the Treaty of Amity. The Court then finds that "even if it were shown that the Applicant's conduct was not beyond reproach, this would not be sufficient per se to uphold the objection to admissibility raised by" the United States. ${ }^{152}$ It does so "[w]ithout having to take a position on the 'clean hands' doctrine", though. 153

In Jadhav, a case relating to the right to consular assistance under the 1963 Vienna Convention on Consular Relations, Pakistan asked the Court to declare

148 Immunities and Criminal Proceedings (Equatorial Guinea v. France), Preliminary Objections, Judgment, I.C.J. Reports 2018, paras. 150-151 (discussed in Bordin, "Procedural Developments at the International Court of Justice", 18 The Law and Practice of International Courts and Tribunals (2019), 101, 110-113).

149 Certain Iranian Assets, para. 107.

150 Ibid., para. 108.

151 Ibid., para. 114.

$15^{2}$ Ibid., para. 122.

153 Ibid. 
India's claims inadmissible because of India's previous conduct, invoking both the "clean hands" doctrine and the principles ex turpi causa non oritur actio and ex injuria jus non oritur. That was because India had "failed to respond to its request for assistance with the investigation into Mr. Jadhav's activities"; had "provided him with a 'false cover name authentic passport"; and was "responsible for Mr. Jadhav's espionage and terrorism activities in Pakistan".154 The Court denies that "an objection based on the 'clean hands' doctrine may by itself render an application based on a valid title of jurisdiction inadmissible".155 It also dismisses Pakistan's arguments based on ex turpi causa non oritur actio and ex injuria jus non oritur, ${ }^{156}$ on the grounds that Pakistan had failed to explain "how any of the wrongful acts allegedly committed by India may have prevented Pakistan from fulfilling its obligation in respect of the provision of consular assistance to Mr. Jadhav".157

In Alleged Violations of the 1955 Treaty of Amity, the United States sought to persuade the Court that, by artificially instituting proceedings which in fact related to the JCPOA, Iran was "seeking to obtain 'an illegitimate advantage' in respect of its nuclear activities" with the aim "to bring "political and psychological pressure on the United States". ${ }^{158}$ The Court dismisses the objection by noting that if it were to find that the United States has indeed breached the Treaty of Amity (as argued by Iran), this would be on the basis of "an examination by the Court of the treaty provisions that are encompassed within its jurisdiction" and would not thus "imply giving Iran any 'illegitimate advantage' with respect to its nuclear programme". ${ }^{159}$ More broadly, the Court recalls a dictum from the Border and Transborder Armed Actions (Nicaragua v. Honduras) case to the effect that it "cannot concern itself with the political motivation which may lead a State at a particular time, or in particular circumstances, to choose judicial settlement". 160 The Court observes that Iran's decision to challenge sanctions that were also addressed by the JCPOA "may reflect a policy decision", but that doing so did not constitute an abuse of process. ${ }^{161}$

Abuse of process was the focus of Judge ad hoc Brower's Separate Opinion in Alleged Violations of the 1955 Treaty of Amity, where he partly concurs and partly dissents from the Court's judgment on preliminary objections. Judge

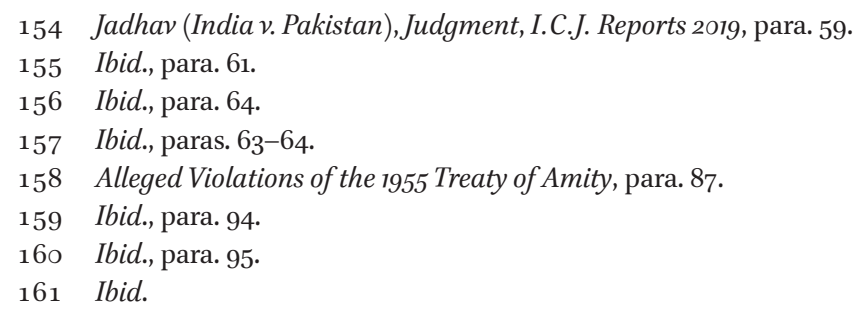


ad hoc Brower provocatively suggests that "abuse of process has become the holy grail of international law as applied by the Court and its predecessor ..., i.e. something in which this Court fervently believes, but the actual shape, substance and content of which the Court never has ascertained". 162 He chronicles past references to abuse of rights and abuse of process in the jurisprudence of the ICJ and its predecessor, and suggests that "[i]t is as though the Court is determined to continue 95 years of enshrouding the principle of abuse of process in mystery, leaving consequently unedified litigants wondering whether the Court itself knows its substance, let alone the threshold for its application". ${ }^{163}$ Turning to the facts of the case, he criticises the Court for allowing itself to be indirectly asked to enforce the provisions of the JCPOA, which remains, as he emphasises, a non-binding instrument. To his mind, the Court's neglect of the concept of abuse of process "most definitely must disincentivize States from seeking to fulfil their obligations under the Charter of the United Nations by means that are not legally binding".164

An interesting question that the Certain Iranian Assets and Jadhav cases raise concerns the status of the "clean hands" doctrine in international law. While the Court seems to leave that question open in Certain Iranian Assets, by indicating that it did not have to take a position on it, the language employed in Jadhav could be viewed as a more categorical rejection of the doctrine. In his Declaration in the Jadhav case, Judge Iwasawa endorses the majority's position and observes that "[a]n objection based on the clean hands doctrine may make an application inadmissible only in exceptional circumstances". ${ }^{165}$ But after the Court's statement that "an objection based on the 'clean hands' doctrine may [not] by itself render an application based on a valid title of jurisdiction inadmissible", 166 is there much room left to argue that jurisdiction to hear a claim must be declined because the party that brought that claim has "unclean hands"? It remains to be seen whether States will keep invoking the "clean hands" doctrine in future cases.

\subsection{Exhaustion of Local Remedies}

In Application of the ICSFT and CERD, Russia asked the Court to declare Ukraine's claims under CERD inadmissible on the grounds that the individuals affected by the measures that Ukraine complained of had failed to exhaust

\footnotetext{
162 Alleged Violations of the 1955 Treaty of Amity, Separate Opinion of Judge ad hoc Brower, para. 1.

163 Ibid., paras. 5-11.

164 Ibid., para. 12.

165 Jadhav, Declaration of Judge Iwasawa, para. 3.

166 Jadhav, para. 61.
} 
local remedies. In its judgment, the Court reaffirms its long-standing position that "local remedies must be previously exhausted as a matter of customary international law in cases in which a State brings a claim on behalf of one or more of its nationals". 167 It does not consider the rule to be applicable to the case, however. That was due to the fact that Ukraine did not "adopt the cause of one or more of its nationals, but challenges, on the basis of CERD, the alleged pattern of conduct of the Russian Federation with regard to the treatment of the Crimean Tatar and Ukrainian communities in Crimea".168 The Court does not cite its previous judgment in the Avena case, but, to borrow from that judgment's language, Ukraine is viewed as "making a claim in its own right". 169

\subsection{Appropriateness of Dealing with Aspects of Larger Disputes}

In her dissenting opinion in Application of the ICSFT and CERD, Vice-President Xue contends that it would be inappropriate for the Court to rule on a claim that is inseparable from an "overall problem" over which it has no jurisdiction. She believes that " $[\mathrm{t}] \mathrm{o}$ characterize military and financial support from Russia's side, by whomever possible, as terrorism financing, would inevitably bear the legal implication of defining the nature of the armed conflict in eastern Ukraine, which ... extends well beyond the limit of the Court's jurisdiction under the ICSFT". ${ }^{170}$ Because there would be "an inseparable connection" between Ukraine's claims under the ICSFT and that armed conflict, the Court would not be "[j]udicially ... in a position to resolve the dispute as presented by Ukraine". ${ }^{171}$

While Vice-President Xue makes those points in discussing the Court's jurisdiction ratione materiae under the ICSFT, the argument that she articulates might be better described as an argument pertaining to the admissibility of

167 Application of the ICSFT and CERD, para. 129.

168 Ibid., para. 13o. The majority's position, and the rationale of the rule of the exhaustion of local remedies in human rights cases, is discussed in the Separate Opinion of Judge Cançado Trindade, paras. 29-43.

169 Avena and Other Mexican Nationals (Mexico v. United States of America), Judgment, I.C.J. Reports 2004, para. 42. In Avena, the Court dealt with "special circumstances of interdependence of the rights of the State and of individual rights" under Article 36 of the Vienna Convention on Consular Relations. It found that Mexico was entitled, "in submitting a claim in its own name", to "request the Court to rule on the violation of rights which it claims to have suffered both directly and through the violation of individual rights conferred on Mexican nationals", and observed that "[t]he duty to exhaust local remedies does not apply to such a request" (para. 40).

170 Application of the ICFST and CERD, Dissenting Opinion of Vice-President Xue, para. 5 .

171 Ibid. 
claims. Her suggestion is not so much that the parties have not consented to the Court's deciding a dispute arising under the ICSFT, but that doing so would be inappropriate insofar as it would require the Court to rule on a larger dispute that lies outside its purview. After all, Vice-President Xue refers to "[j]udicial policy" and posits that "[l]oose expansion of the scope of the Court's jurisdiction will not be conducive to the peaceful settlement of international disputes, when judicial restraint is clearly called for under the circumstances". ${ }^{12}$

One can see a certain parallelism between Vice-President Xue's remarks and the so-called Monetary Gold principle, according to which it is inappropriate for the Court to settle a dispute over which it has jurisdiction if doing so would require it to rule on the rights and obligations of an absent third party. But in the scenario that she discussed, what would make it inappropriate for the Court to rule is not the lack of consent of an absent third party, but rather the absence of consent by the respondent if the broader dispute cannot be meaningfully separated from the dispute over which the Court has jurisdiction.

It should be noted that Vice-President Xue's position, as interesting a contribution to the ongoing debate on judicial policy and judicial propriety though it may be, does not sit easily with the Court's firmly held position that it is entitled to exercise jurisdiction over discrete aspects of larger disputes. As reported above, that position was recently reiterated in the Alleged Violations of the 1955 Treaty of Amity case.

In the period reported, the Court heard two requests for provisional measures in the cases concerning Application of CERD (Qatar v. UAE) and Application of the Convention on the Prevention and Punishment of the Crime of Genocide (Myanmar v. The Gambia). In its respective orders, the Court adhered to the analytical framework that has become a constant in its orders on provisional measures indicated under Article 41 of the ICJ Statute. That comprises an examination of prima facie jurisdiction; plausibility of the rights invoked and their link with the provisional measures requested; and risk of irreparable prejudice and urgency. ${ }^{173}$

172 Ibid., para. 11.

173 See Application of the International Convention on the Elimination of All Forms of Racial Discrimination (Qatar v. United Arab Emirates), Provisional Measures, Order of 14 June 2019, I.C.J. Reports 2019, paras. 15, 17-18. 


\subsection{Application of CERD (Qatarv. UAE)}

In its Order of 14 June 2019 in Application of CERD (the "2019 Order"), the Court rejects a request by the United Arab Emirates for provisional measures aiming at having Qatar (i) withdraw proceedings instituted before the CERD Committee; (ii) stop hindering the UAE's attempts to assist Qatari citizens in compliance with the provisional measures indicated by the Court on 23 July 2018 (the " 2018 Order"); (iii) stop Qatari institutions and government-controlled media from disseminating "false accusations" in relation to the matters pending before the Court; and (iv) refrain from actions which might aggravate the dispute. ${ }^{174}$

The issue of prima facie jurisdiction is disposed of quickly, with the Court recalling its 2018 Order indicating provisional measures on Qatar's request in the same case. Having found jurisdiction prima facie in that Order, ${ }^{175}$ it sees "no reason to revisit [that] previous finding". 176 The Court finds, however, that neither the first nor the second provisional measures requested by the UAE concerned plausible rights under CERD. ${ }^{177}$ The Court also rejects the third and the fourth requested measures, on the grounds that provisional measures aimed at preventing the further aggravation of a dispute can only be indicated "as an addition to specific measures to protect rights of the parties". ${ }^{178}$ The Court notes, in any event, that the 2018 Order already comprised measures aimed at preventing the further aggravation of the dispute. ${ }^{179}$

While the 2019 Order was adopted by a majority of fifteen to one, with the sole dissent of Judge ad hoc Cot, its reasoning attracted the criticism of several judges.

Judges Tomka, Gaja, Gevorgian and Salam recalled their position that the dispute did not fall within the scope of CERD, which had already been stated in their opinions to the 2018 Order. ${ }^{180}$

Vice-President Xue and Judge Abraham convincingly criticise the Court for taking an excessively narrow approach to its powers under Article 41 of the ICJ Statute, each focusing on different sections of the 2019 Order. Judge

174 Ibid., paras. 12 and 32.

175 Application of the International Convention on the Elimination of All Forms of Racial Discrimination (Qatarv. United Arab Emirates), Provisional Measures, Order of 23July 2018, I.C.J. Reports 2018 (discussed in Bordin, "Procedural Developments at the International Court of Justice", 18 The Law and Practice of International Courts and Tribunals (2019), 101, 116-117).

176 Application of CERD, Order of 14 June 2019, para. 15.

177 Ibid., para. 25 .

178 Ibid., para. 28.

179 Ibid., para. 29 .

180 Application of CERD, Order of 14 June 2019, Joint Declaration of Judges Tomka, Gaja and Gevorgian, para. 2; Declaration of Judge Salam, para. 1. 
Abraham is troubled by how the Court articulates its analysis when rejecting the first and second measures sought by the UAE. The words chosen by the Court would "seem to exclude the possibility of provisional measures proceedings being instituted by a party with a view to obtaining provisional protection for its procedural rights during the judicial process itself", limiting them to "provisional protection of the rights ... under the legal instrument that forms the basis of the Court's jurisdiction and determines the substantive law applicable to the merits of the case". ${ }^{181}$ To Judge Abraham's mind, the link between measures and rights that the case law of the Court requires, though no doubt central, "is not a convincing reason to exclude, on principle, provisional measures aimed at protecting other types of rights: the right to procedural fairness, the right to equality of arms or the right to sound administration of justice, which may also - albeit exceptionally - be affected by one party's conduct towards another". ${ }^{182} \mathrm{He}$ would have preferred the Court to recognise expressly that such "other types of rights" may also qualify as "respective rights of either party" in the sense of Article 41. The inference could otherwise be that the ICJ has no power to indicate provisional measures to protect procedural rights affected by "a party's extrajudicial conduct, that is, an act external to the judicial process itself". 183

On her part, Vice-President Xue focuses on the Court's reason for rejecting the third and fourth measures requested by the UAE, namely that measures of non-aggravation can only be indicated as an addition to specific measures aimed at protecting the rights of the parties. In her view, "such a restrictive qualification may unduly restrain the power of the Court".184 Recalling that Article 41 of the ICJ Statute empowers the Court to indicate provisional measures propio motu or to indicate measures other than those requested by the

\footnotetext{
181 Application of CERD, Order of 14 June 2019, Separate Opinion of Judge Abraham, para. 21. 182 Ibid., para. 25 .

183 Ibid. In paragraph 27, Judge Abraham then explains: "To return to the present case, I am of the view that although the first two measures requested by the UAE had to be rejected, it is not because the rights which the requested measures sought to protect were not plausible 'under CERD'. It is true that these alleged rights - the right to procedural fairness and the right not to suffer any interference with the implementation of a provisional measure ordered by the Court - do not, in the UAE's case, derive from CERD itself (not, in any event, from its substantive provisions): these are rights - the first, certain, but the second, questionable - that the State would have in its capacity as a party to the judicial proceedings on the basis of the Statute, not the provisions of the treaty with which compliance constitutes the subject-matter of the dispute. However, in my opinion, this is not the right reason for rejecting the measures requested."

184 Application of CERD, Order of 14 June 2019, Declaration of Vice-President Xue, para. 3.
} 
parties, ${ }^{185}$ Vice-President Xue emphasises the contribution that the Court can and ought to make to the maintenance of international peace and security. The Court's role requires it to be "mindful of the broader situation in which a particular case is situated" and also includes "the 'duty' to indicate ... such provisional measures as may conduce to the due administration of justice".186 For those reasons, Vice-President Xue regrets that the 2019 Order may give the impression that measures of non-aggravation have a mere "secondary" character. ${ }^{187}$

Finally, Judge ad hoc Cot's dissent focuses on the Court's rejection of the first measure requested by the UAE. Referring to the doctrine of lis pendens, he contends that the UAE was facing a risk of irreparable damage because of the existence of parallel proceedings before the ICJ and the CERD Committee. The risk was that "an unsatisfactory defence on the part of the UAE, as a result of the parallel proceedings, may irreparably influence the final decisions of the Court or the CERD Committee, or both". 188 Judge ad hoc Cot did not suggest that the risk would only be eliminated if the Court ordered Qatar to withdraw its complaint before the CERD Committee: the Court could have instead asked Qatar to suspend the proceedings before the CERD Committee or decided to suspend its own proceedings until the CERD Committee took a position. ${ }^{189}$

\subsection{Application of the Genocide Convention (The Gambia v. Myanmar)}

In November 2019, The Gambia instituted proceedings against Myanmar alleging several breaches of the 1948 Convention on the Prevention and Punishment of the Crime of Genocide in connection with serious abuses committed against Rohingya Muslims in Myanmar. The Gambia asked the Court to indicate provisional measures of protection, a request that the Court accepted in a unanimous Order on 23 January 2020. The Court directs Myanmar to take all measures within its power to prevent acts of genocide; ensure that its agents or people under its control are not involved in genocidal acts; take "effective measures" to protect evidence relating to The Gambia's allegation; and submit periodic reports on all measures taken in compliance with the Order. 190

\footnotetext{
185 Ibid., para. 4.

186 Ibid., para. 6.

187 Ibid.

188 Application of CERD, Order of 14 June 2019, Dissenting Opinion of Judge ad hoc Cot, para. 20.

189 Ibid., para. 22.

190 Application of the Convention on the Prevention and Punishment of the Crime of Genocide (The Gambia v. Myanmar), Provisional Measures, Order of 23 January 2020, I.C.J. Reports 2020, para. 86.
} 
The case was brought under the compromissory clause in Article IX of the Genocide Convention. Considering its prima facie jurisdiction, the Court thus sought to determine "whether the acts complained of by the Applicant are capable of falling within the provisions of that instrument and whether, as a consequence, the dispute is one which the Court has jurisdiction ratione materiae to entertain". 191 The Court provisionally concludes, upon examining the record, that a dispute between the parties concerning the application of the Genocide Convention exists, ${ }^{192}$ and that the acts that Myanmar has allegedly committed are capable of falling within the provisions of the Convention. ${ }^{193}$ The Court also provisionally dismisses an argument by Myanmar that its reservation to Article viII of the Convention (entitling the parties to call upon UN organs to take action for the prevention and suppression of genocides) would deprive it of jurisdiction. That was because Myanmar had made no reservation to Article IX and Articles VIII and IX "have distinct areas of application". 194

Having found that it has prima facie jurisdiction, the Court provisionally rejects an objection to the request for provisional measures based on The Gambia's alleged lack of standing to invoke Myanmar's responsibility under the Genocide Convention. Myanmar's argument was that The Gambia was not specially affected by Myanmar's alleged breaches of the Convention. Recalling previous remarks made in the advisory opinion on Reservations to the Convention on the Prevention and Punishment of the Crime of Genocide and in the judgment on preliminary objections in Questions relating to the Obligation to Prosecute or Extradite, the Court finds that the Genocide Convention creates obligations erga omnes partes. It follows that "any State party to the Genocide Convention, and not only a specially affected State, may invoke the responsibility of another State party with a view to ascertaining the alleged failure to comply with its obligations erga omnes partes, and to bring that failure to an end". 195 The Court thus concludes that The Gambia also has "prima facie standing" to bring the case against Myanmar. ${ }^{196}$

Looking into the plausibility of the rights invoked by The Gambia, and their link with the provisional measures requested, the Court observes that "the Rohingya in Myanmar appear to constitute a protected group within the meaning of Article II of the Genocide Convention",197 and that the "facts and

\footnotetext{
191 Ibid., para. 20.

192 Ibid., paras. 27-28.

193 Ibid., para. 3 .

194 Ibid., para. 35 .

195 Ibid., para. 41.

196 Ibid., para. 42.

197 Ibid., para. $5^{2}$
} 
circumstances" adduced were "sufficient" for it to conclude that the rights claimed by The Gambia - in particular, to demand that Myanmar refrain from committing genocide and take the necessary measures to prevent and punish it - are plausible. ${ }^{198}$ It rejects Myanmar's argument that "the exceptional gravity of the allegations" would be "a decisive factor warranting ... the determination, at the present stage of the proceedings, of the existence of a genocidal intent". ${ }^{199}$ The Court also accepts that there is a link between those rights and most of the measures sought by The Gambia - except for The Gambia's request that Myanmar "grant access to, and cooperate with, all United Nations factfinding bodies that are engaged in investigating alleged genocidal acts against the Rohingya", ${ }^{200}$ which the Court does not consider "necessary in the circumstances of the case". ${ }^{201}$

When it comes to the risk of irreparable prejudice and urgency, the Court recalls that its powers under Article 41 of the ICJ Statute can be exercised when "irreparable prejudice could be caused to rights which are the subject of judicial proceedings or when the alleged disregard of such rights may entail irreparable consequences", and "when there is a real and imminent risk that irreparable prejudice will be caused before the Court gives its final decision". ${ }^{202}$ The Court stresses the "fundamental values sought to be protected by the Genocide Convention" and observes that the rights of the Rohingya to be protected from acts that threaten its existence as a group "are of such a nature that prejudice to them is capable of causing irreparable harm". ${ }^{203}$ Examining the record, the Court further finds that "the Rohingya in Myanmar remain extremely vulnerable". ${ }^{204}$ Though the Court acknowledges a statement made by Myanmar during the oral proceedings outlining steps that it is purportedly taking to address the situation, it rules that "these steps do not appear sufficient in themselves to remove the possibility" of irreparable prejudice. ${ }^{205}$

Having concluded that the requirements for the indication of provisional measures were met, the Court articulates, at the end of the Order, the measures to be taken by Myanmar. In so doing, it recalls that "the measures to be indicated need not be identical to those requested". 206

\footnotetext{
198 Ibid., para. 56 .

199 Ibid.

200 Ibid., para. 12.

201 Ibid., para. 62.

202 Ibid., paras. 64-65.

203 Ibid., para. 70.

204 Ibid., para. 72.

205 Ibid., para. 73.

206 Ibid., para. 78.
} 
Three judges offered individual reflections on the Court's unanimous order. Vice-President Xue expressed reservations as to whether the acts The Gambia complains of can constitute genocide and whether The Gambia has standing to bring the case against Myanmar. She accepts that determining the existence of an intent to commit genocide is not required for the indication of provisional measures, but advocates for "a minimum standard to be applied at this early stage", whereby the Court has to "determine, prima facie, that the subjectmatter of the dispute between the Parties could possibly concern genocide". 207 She is not convinced that The Gambia's submissions would meet such a minimum standard, as "[t]he evidence and documents submitted to the Court ..., while displaying an appalling situation of human rights violations, present a case of a protracted problem of ill-treatment of ethnic minorities in Myanmar rather than of genocide". ${ }^{208}$ As regards standing, Vice-President Xue recalls the position she adopted in dissenting from the majority in the Belgium v. Senegal case. She doubts that, "on the basis of public international law and practice as it stands today", a State that is not injured can institute proceedings against another before the ICJ on the basis of a breach of obligations erga omnes partes. ${ }^{209}$ Despite those misgivings, Vice-President Xue votes together with the majority in the light of "the gravity and scale of the alleged offences", the role that the Court can play in helping "control ... the situation", and the situation of vulnerability in which the Rohingya find themselves. ${ }^{210}$

The vulnerability of the Rohingya is also front and centre in Judge Cançado Trindade's Separate Opinion. He observes that "[i]nvocation of extreme human vulnerability is a key element to be taken into account in a decision concerning provisional measures of protection" in a case concerning matters such as genocide. ${ }^{211} \mathrm{He}$ finds human vulnerability to be "a test more compelling" than that of plausibility of rights, and points out that provisional measures "have been protecting growing numbers of persons in situations of extreme

207 Application of the Genocide Convention (The Gambia v. Myanmar), Provisional Measures, Separate Opinion of Vice-President Xue, para. 2.

208 Ibid., para. 3.

209 Ibid., para. 5. This is a point that is likely to be litigated extensively in the next phase of the case, as the position taken by the Court is formally provisional. But there is a sense of definitiveness in how the Court approaches it in the Order that casts some doubt as to whether Vice-President Xue's protestations will find much purchase in the bench. It would take, after all, a full departure from the approach taken in Belgium v. Senegal for the Court to refuse to decide on the merits of The Gambia's application for lack of standing.

210 Ibid., paras. 9-11.

211 Application of the Genocide Convention (The Gambia v. Myanmar), Provisional Measures, Separate Opinion of Judge Cançado Trindade, para. 72. 
vulnerability" and have therefore "been transformed into a true jurisdictional guarantee of preventive character". ${ }^{212}$

Judge ad hoc Kress's Separate Opinion echoes some of the concerns expressed by Vice-President Xue as regards the plausibility test applied by the majority. While he agrees that a case involving serious allegations should not as such require a stricter plausibility test, he describes the standard applied by the Court as "low" and admits to having come to the conclusion that "the plausibility test was met with respect to the question of genocidal intent" with some hesitation. ${ }^{213} \mathrm{He}$ would have liked the Court to be more emphatic in stating that the Order's findings "in no way whatsoever prejudges the merits". ${ }^{214}$

\section{$7 \quad$ Procedural Developments in Advisory Proceedings}

On 25 February 2019, the Court issued an advisory opinion on Legal Consequences of the Separation of the Chagos Archipelago from Mauritius in 1965. As usual, the first part of the opinion deals with questions of jurisdiction and admissibility. The Court unanimously found that it had jurisdiction to give the opinion, given that an opinion on a legal question had been requested by the UN General Assembly, as authorised by the UN Charter. The requirements in Article 96 of the UN Charter and Article 65 of the ICJ Statute had thus been met. ${ }^{215}$

Most of the procedural analysis revolved around the question of whether the Court ought to exercise its discretion to decline to comply with the General Assembly's request. Relying on its previous jurisprudence, the Court recalls that " $[t]$ he discretion whether or not to respond to a request for an advisory opinion exists so as to protect the integrity of the Court's judicial function as the principal judicial organ of the United Nations", but that issuing advisory opinions "represents its participation in the activities of the Organization, and, in principle, should not be refused". ${ }^{216}$ Only "compelling reasons" would justify the Court's refusal to give an opinion falling within its jurisdiction. ${ }^{217}$

\footnotetext{
212 Ibid., para. 92.

213 Application of the Genocide Convention (The Gambia v. Myanmar), Provisional Measures, Separate Opinion of Judge ad hoc Kress, paras. 4-5.

214 Ibid., paras. 6-7 (also suggesting that the Court should have been more circumspect in observing that the Rohingya appears to be a group protected by the Genocide Convention).

215 Legal Consequences of the Separation of the Chagos Archipelago from Mauritius in 1965, Advisory Opinion, I.C.J. Reports 2019, paras. 55-62.

216 Ibid., paras. 64-65.

217 Ibid., para. 65.
} 
The Court then considers four potential "compelling reasons" that some States participating in the proceedings adduced to persuade it to exercise its discretion. First, there was the contention that advisory proceedings might not be suitable for the determination of the "complex and disputed factual issues" surrounding the excision of the Chagos Archipelago from Mauritius in 1965. The Court rejects it by noting that it had been provided with "an abundance of material", including contemporaneous official records of the relevant events of the 196os. ${ }^{218}$

Second, the Court deals with the claim that its opinion would not assist the General Assembly in the performance of its functions. That argument has been made, addressed and rejected in several previous opinions, with the Court remaining firmly committed to the policy of never second-guessing the requesting organ. In its Opinion on Chagos, the Court thus restates that "it is not for the Court itself to determine the usefulness of its response to the requesting organ". ${ }^{219}$

Third, the Court considers the suggestion that it would not be appropriate for it to re-examine a question that had been settled by the award of the Arbitral Tribunal constituted under UnClos Annex VII in the Arbitration regarding the Chagos Marine Protected Area case. The Court briefly disposes of the argument, explaining that the opinion is given to the requesting organ rather than to States; that "the principle of res judicata does not preclude it from rendering an advisory opinion"; and that, in any event, the issues covered by the Arbitral Tribunal's award were different from those which the Court was being asked to address in the proceedings. ${ }^{220}$

Fourth, the Court turns to what was no doubt the most pertinent of the four potential "compelling reasons" invoked: the suggestion that the UN General Assembly's request related to a pending dispute between two States that had not consented to bring it before the Court. In its advisory opinion on Western Sahara in 1970, the Court expressly recognised that "lack of consent might constitute a ground for declining to give the opinion requested". ${ }^{221}$ For the Court, lack of consent would render "the giving of an advisory opinion incompatible with the Court's judicial character" if this "would have the effect of circumventing the principle that a State is not obliged to allow its disputes to be submitted to judicial settlement without its consent". ${ }^{222}$ Some participants in

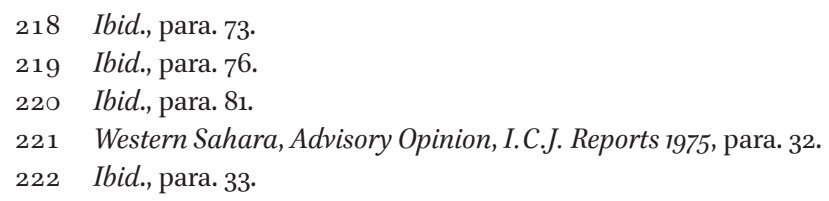


the proceedings invited the Court to take that route, arguing that the question of the legal consequences of the separation of the Chagos Archipelago from Mauritius constituted a bilateral dispute between the United Kingdom and Mauritius, the judicial settlement of which the United Kingdom had clearly and emphatically opposed.

By twelve votes to two, the Court decides that it was appropriate to give the opinion because "the questions put to it by the General Assembly relate to the decolonization of Mauritius". 223 In the Court's view, the General Assembly had not sought an opinion to resolve a territorial dispute between two States. Rather, the purpose of the request was "for the General Assembly to receive the Court's assistance so that it may be guided in the discharge of its functions relating to the decolonization of Mauritius". ${ }^{224}$ Recalling the General Assembly's "long and consistent record in seeking to bring colonialism to an end", the Court finds that the "issues raised by the request are located in the broader frame of reference of decolonization", a matter "which is of particular concern to the United Nations". 225 That being the case, "to give the opinion requested would [not] have the effect of circumventing the principle of consent by a State to the judicial settlement of its dispute with another State". 226

Judges Tomka and Donoghue voted against the Court's decision to give the advisory opinion.Judge Donoghue believes that the decolonization of Mauritius and the bilateral dispute about sovereignty over the Chagos Archipelago between Mauritius and the United Kingdom "cannot be separated". ${ }^{227}$ To her mind, by giving the advisory opinion, the Court "has decided the very issues that Mauritius has sought to adjudicate" and "to which the United Kingdom has refused to give its consent". 228 She criticises the Court's finding that the legal questions asked by the General Assembly were located in "a broader frame of reference", observing that "any bilateral dispute that attracts sufficient support in the General Assembly so as to lead that organ to request an advisory opinion could be described as falling within a "broader frame of reference". 229 Her fear is that the Court is "[signalling] that the advisory opinion procedure

\footnotetext{
223 Legal Consequences of the Separation of the Chagos Archipelago, para. 86.

224 Ibid., para. 86.

225 Ibid., para, 88.

226 Ibid., para. 9o. See further Zeno Crespi Reghizzi, "The Chagos Advisory Opinion and the Principle of Consent to Adjudication", in Thomas Burri and Jamie Trinidad (eds.), The International Court of Justice and Decolonization (2021).

227 Legal Consequences of the Separation of the Chagos Archipelago, Dissenting Opinion of Judge Donoghue, para. 16.

228 Ibid., para. 19.

229 Ibid., para. 20.
} 
is available as a fall-back mechanism to be used to overcome the absence of consent to jurisdiction in contentious cases", which would "[undermine] the integrity of the Court's judicial function". 230

A similar sentiment is shared by Judge Tomka, who expresses concern that "advisory proceedings have now become a way of bringing before the Court contentious matters, with which the General Assembly had not been dealing prior to requesting an opinion upon an initiative taken by one of the parties to the dispute". 231 The focus of Judge Tomka's analysis is, however, not so much on the nature of the dispute between the United Kingdom and Mauritius, but rather on the fact that the General Assembly had "not dealt with the issue of the Chagos Archipelago for half a century". ${ }^{232}$ Judge Tomka also criticises the Court for "[going] further than what was required to assist the General Assembly and [intruding] upon the bilateral dispute between Mauritius and the United Kingdom". ${ }^{233} \mathrm{He}$ takes issue with the Court's finding, in its answer to the UN General Assembly, that the United Kingdom had committed "an unlawful act of a continuing character" by not completing the decolonization of Mauritius. ${ }^{234} \mathrm{He}$ does not think that such a finding of State responsibility was required for the purpose of giving advice on the law that applies to decolonization. ${ }^{235}$

Vice-President Xue, who voted with the majority, offers a counterpoint to the individual opinions of the two dissenting judges, in particular to Judge Donoghue's. Her views can be summarised in the form of three propositions. First, the scope of the main question asked by the General Assembly was "specifically defined", as it concerned "the legal status of the decolonization process of Mauritius at a particular point of time, namely, at the time when Mauritius was granted independence in $1968^{\prime, 236}$ as opposed to a bilateral territorial

230 Ibid., para. 23.

231 Legal Consequences of the Separation of the Chagos Archipelago, Declaration of Judge Tomka, para. 2 .

232 Ibid., paras. 4-5.

233 Ibid., para. 7 .

234 Legal Consequences of the Separation of the Chagos Archipelago, para. 177.

235 For similar points, see Legal Consequences of the Separation of the Chagos Archipelago, Declaration of Judge Gevorgian, paras. $5^{-6}$ and Dissenting Opinion of Judge Donoghue, para. 22. For a discussion of questions of judicial propriety arising when the ICJ makes findings of State responsibility in advisory opinions, see Fernando L. Bordin, "State Responsibility in Advisory Proceedings: Thoughts on Judicial Propriety and Multilateralism in the Chagos Opinion", in Thomas Burri and Jamie Trinidad (eds.), The International Court of Justice and Decolonization (2021), 96-104.

236 Legal Consequences of the Separation of the Chagos Archipelago, Declaration of VicePresident Xue, para. 6. 
dispute between the parties that may have emerged later in time. Second, "both the United Kingdom itself and the United Nations treated the detachment of the Chagos Archipelago as a matter of decolonization rather than a territorial issue". ${ }^{237}$ She adds that, at the relevant time, "there was no dispute between the administering Power and the colony of Mauritius over the fact that the Chagos Archipelago had always constituted part of the territory of Mauritius". 238 Third, the fact that Mauritius has sought to exercise its "substantive right ... to resolve the issue of the Chagos Archipelago with the United Kingdom through bilateral and third-party procedures" does not "change the nature of the issue as a matter of decolonization" or "deprive the General Assembly of its mandate on decolonization under the Charter of the United Nations". 239

And it is indeed the case that the approach taken in Chagos is in keeping with previous cases where the Court gave opinions on issues that constituted disputes between States but had also been on the UN agenda. ${ }^{240}$ The Chagos opinion confirms the Court's tendency, in considering the scope of its discretion, to give precedence to the multilateral aspects of requests for an advisory opinion over their bilateral aspects. That has been how the Court has thus far understood its duty to contribute to the activities of the UN as the organization's "principal judicial organ".

237 Ibid., para. 9.

238 Ibid., para. 13 .

239 Ibid., para. 19.

240 See Western Sahara, paras. 39-41 and Legal Consequences of the Construction of a Wall in the Occupied Palestinian Territory, Advisory Opinion, I.C.J. Reports, paras. 46-50. 